\title{
Proteomic characterization of reversible thiol oxidations in proteomes and proteins
}

\author{
Susanna Boronat*, Alba Domènech and Elena Hidalgo* \\ Oxidative Stress and Cell Cycle Group, Universitat Pompeu Fabra, C/ Dr. Aiguader 88, 08003 \\ Barcelona, Spain \\ ${ }^{*}$ Correspondence should be addressed to E.H. Tel.: 34-93-316-0848; Fax.: 34-93-316-0901; E-mail: \\ elena.hidalgo@upf.edu or to S.B. Tel.: 34-93-316-0819; Fax.: 34-93-316-0901; E-mail: \\ susanna.boronat@upf.edu
}

The first two authors contributed equally to this work

Running head: Proteomics of reversible thiol oxidations Keywords: thiol switch $-\mathrm{H}_{2} \mathrm{O}_{2}-$ Cys oxidation - redox proteomics - ICAT

7521 words (excluding references and figure legends), 114 references, 7 grayscale figures, 


\section{ABSTRACT}

Significance: Reactive oxygen species are produced during normal metabolism in cells, and their excesses have been implicated in protein damage and toxicity, as well as in the activation of signaling events. In particular, hydrogen peroxide participates in the regulation of different physiological processes as well as in the induction of antioxidant cascades, and often the redox molecular events triggering these pathways are based on reversible cysteine oxidation. Recent Advances: Increases in peroxides can cause the accumulation of reversible cysteine oxidations in proteomes, which may be either protecting thiols from irreversible oxidations or may just be reporters of future toxicity. It is also becoming clear, however, that only a few proteins, such as the bacterial OxyR or peroxidases, can suffer direct oxidation of their cysteine residues by hydrogen peroxide, and therefore may be the only true sensors initiating signaling events. Critical Issues: We will here describe some of the methodologies used to characterize at the proteome level reversible thiol oxidations, specifically those combining gel-free approaches with mass spectrometry. In the second part of this review, we will summarize some of the electrophoretic and proteomic techniques used to monitor cysteine oxidation at the protein level, needed to confirm that a protein contains redox cysteines involved in signaling relays, using as examples some of the best characterized redox sensors such as bacterial OxyR or yeast Tpx1/Pap1. Future Directions: While cysteine oxidations are often detected in proteomes and in specific proteins, major efforts have to be made to establish that they are physiologically relevant. 


\section{INTRODUCTION}

The price that organisms have to pay for living in an environment with oxygen is the extent of their energy to cope with the deleterious effects of the oxidation of biomolecules. In evolution, cells have developed complex antioxidant systems to maintain a proper internal redox environment.

The main source of oxidants in eukaryotic cells is the mitochondrial electron transport chain during cellular respiration as a result of the one-electron reduction of molecular oxygen to water. They can also be generated by peroxisomal fatty acid degradation in the beta-oxidation pathway (103), or during oxidative protein folding in the endoplasmic reticulum (104). More specific sources of reactive oxygen species (ROS) and reactive nitrogen species are the enzymatic activities of several enzymes such as nicotinamide adenine dinucleotide phosphate (NADPH) oxidases, mieloperoxidases and nitric oxide synthases, activated in phagocytes in response to microorganisms (56), or the activities of cytochrome P450 and the enzymatic system of hypoxanthine/xanthine oxidase activated in cases of ischemia/reperfusion, metal-catalyzed reactions, osmotic stress and chemotherapeutic drugs $(39,61)$.

The one-electron reduction of oxygen produces superoxide anion, which is converted to hydrogen peroxide $\left(\mathrm{H}_{2} \mathrm{O}_{2}\right)$ by spontaneous dismutation or catalyzed by superoxide dismutase. $\mathrm{H}_{2} \mathrm{O}_{2}$ can be partially reduced to hydroxyl radical or fully reduced to water (105). The reactivity, or oxidation capacity, of these ROS depends on the nature of the chemical species, their cellular concentration, stability and membrane diffusion ability $(43,111)$. Superoxide anion reacts at a rate that is almost diffusion-limited with iron from iron-sulfur clusters, but it does not react so easily with other intracellular compounds due to its charge, which make it unable to diffuse through membranes. On the other hand, the reactivity of hydroxyl radical is so high and indiscriminate that its diffusion is limited to production sites (17). The reactivity of $\mathrm{H}_{2} \mathrm{O}_{2}$, although not very high with iron-sulfur clusters, low molecular weight thiols and thiols in proteins, may be significantly increased depending on the protein environment reaching rate constants of up to $10^{8} \mathrm{M}^{-1} \mathrm{~s}^{-1}(65)$. This relatively high reactivity along with the stable $\mathrm{H}_{2} \mathrm{O}_{2}$ steady-state concentrations $\left(\sim 10^{-7} \mathrm{M}\right)$, half-life $(\sim 1 \mathrm{~ms})$ and ability to diffuse through membranes make $\mathrm{H}_{2} \mathrm{O}_{2}$ one of the ROS more fitted for signaling. Most of this review will describe proteomic techniques used for the characterization of $\mathrm{H}_{2} \mathrm{O}_{2}$-dependent protein oxidation.

One of the most reactive groups of amino acid side chains are thiols from cysteine (Cys) 
residues. Both one-electron and two-electron oxidants are able to react with thiols (-SH), although yielding different products (112). A scheme depicting the different oxidation states of a thiol group upon $\mathrm{H}_{2} \mathrm{O}_{2}$ is shown in Figure 1. Two-electron oxidants such as $\mathrm{H}_{2} \mathrm{O}_{2}$ generate sulfenic acid (-SOH) as the initial product. Sulfenic acid is highly reactive; its reaction with other thiols results in mixed disulfides with glutathione (Prot-S-SG), intramolecular disulfides (-S-S-) favored by vicinal thiols, or inter-molecular disulfides between proteins, whereas in the presence of proximal nitrogen it may form a sulfenamide. Finally, in the presence of stronger oxidants or in the continuous presence of mild oxidants, sulfenic acid may become further oxidized to sulfinic $\left(-\mathrm{SO}_{2} \mathrm{H}\right)$ or sulfonic $\left(-\mathrm{SO}_{3} \mathrm{H}\right)$ acids. One electron oxidation of thiols produces thiyl radicals, which readily react with the thiolate anion ultimately resulting in disulfide bond formation.

Regarding Cys oxidation, the oxidized forms sulfenic acid, disulfide bond, sulfenamide, and, occasionally, sulfinic acid are the only ROS-driven protein modifications that can be repaired in cells thanks to specific cellular activities. Thus, the thioredoxin (Trx) and the glutathione/glutaredoxin (GSH/Grx) systems to be described below reduce disulfide bonds. The reactivity of $\mathrm{H}_{2} \mathrm{O}_{2}$ with specific Cys residues in proteins to generate these reversible modifications provides the basis by which $\mathrm{H}_{2} \mathrm{O}_{2}$ engages in intracellular signaling, since this Cys modification is fast and reversible, two conditions for signaling $(37,84,108)$. This high reactivity, however, cannot be generalized to all Cys residues in proteins. The major determinants of Cys reactivity towards $\mathrm{H}_{2} \mathrm{O}_{2}$ are the available fraction of the Cys thiol in the thiolate form, its capacity to act as a nucleophile to attack the $\mathrm{H}_{2} \mathrm{O}_{2}$ electrophile through a nucleophilic type 2 substitution, and the ability to stabilize the transition state with the reactant, $\mathrm{H}_{2} \mathrm{O}_{2}$. Firstly, Cys thiols with low pKa are expected to have a higher ionized fraction at neutral $\mathrm{pH}$, and this enhanced thiolate availability is important for reactivity; low pKa is mainly achieved by hydrogen bonding interactions of the sulfur atom with the surrounding environment stabilizing the negative charge of the thiolate (86). However, not only the pKa of the thiol group is important for the efficient reaction of a Cys residue with peroxides, since proteins such as tyrosine phosphatases, with a low pKa, do not display reactions rates with $\mathrm{H}_{2} \mathrm{O}_{2}$ as high as peroxiredoxins (Prxs) or glutathione peroxidases (Gpxs) $(23,27,73,102,112)$. Furthermore, in some specific Cys of proteins such as Prxs the protein structural factors stabilizing the thiolate and lowering the pKa also trigger a concomitant decrease in nucleophilicity, and therefore decrease reactivity (27). For the fast reaction rates of a Cys 
residue with peroxides not only the facility to form the thiolate is important, that is, a low pKa, but also the ability to stabilize not only the transition state (where the negative charge of the thiolate is distributed among the sulfur and the two oxygen atoms of $\mathrm{H}_{2} \mathrm{O}_{2}$ ), but also the final product, the leaving group, which occurs after the rupture of the peroxidic bond $(27,38)$.

Only few proteins have Cys residues fulfilling those premises and are therefore particularly prone to react with $\mathrm{H}_{2} \mathrm{O}_{2}$. These Cys residues are called thiol switches, since they can be specifically and reversibly modified by oxidation, leading to a change of activity in the protein. These proteins containing thiol switches are likely to be the direct targets of $\mathrm{H}_{2} \mathrm{O}_{2}$ in signaling cascades, and should be considered $\mathrm{H}_{2} \mathrm{O}_{2}$ sensors. This is the case of the bacterial transcription factor OxyR, and of the $\mathrm{H}_{2} \mathrm{O}_{2}$ scavengers Prxs and Gpxs (see below, section 'Electrophoretic and proteomic approaches to study changes in the Cys oxidation state of specific proteins'). These last type of sensors not only contain Cys residues suitable for reacting with $\mathrm{H}_{2} \mathrm{O}_{2}$, but they are also very abundant and ubiquitous so that they outcompete the reaction of $\mathrm{H}_{2} \mathrm{O}_{2}$ with other targets in the cell to account for the required specificity necessary in signaling [Schizosaccharomyces pombe has around 400,000 molecules of Tpx1, the main Prx in fission yeast, per cell (66)]. Winterbourn and Hampton proposed a mechanism by which sensor proteins when fully oxidized mediate the transfer of oxidation equivalents, probably through thiol disulfide exchanges, to other target proteins through protein-protein interactions (112). An example of such a mechanism is the Tpx1-Pap1 redox relay in S. pombe, in which the Prx Tpx1 transfers the $\mathrm{H}_{2} \mathrm{O}_{2}$-dependent signal to the Pap1 transcription factor, to activate an adaptive response to mild oxidant conditions $(11,12,106)$.

Cys residues are critical not only for sensing responses to oxidants, but also in many essential enzymatic reactions or in the metal coordination of many transcription factors, chaperones and antioxidant enzymes. The accidental oxidation of these Cys is therefore an undesired event that can lead to non-native disulfide bonds being formed between or within proteins, resulting in toxicity due to general protein misfolding. Thus, reversible thiol oxidation upon $\mathrm{H}_{2} \mathrm{O}_{2}$ treatment in whole proteomes has been described in different model systems $(6,32,57)$, suggesting that under certain conditions, peroxides can oxidize solvent exposed Cys. Whether this oxidation is directly mediated by $\mathrm{H}_{2} \mathrm{O}_{2}$ or through an indirect mechanism via oxidized sensor proteins like Prxs or Gpxs is still a matter of debate. 
As mentioned above, cells possess strong antioxidant systems to maintain thiols in their reduced form, which therefore perform the dual role of preventing irreversible damage to proteins and recycling oxidized Cys in enzymes whose enzymatic activity relies on disulfide formation at their active sites (i.e. ribonucleotide reductase, phosphoadenylyl-sulfate reductase, methionine sulfoxide reductase, Prxs, Gpxs) $(49,68,85,90,100)$. Cells have evolved two major systems to control thioldisulfide status: the Trx and the Grx/GSH systems. As depicted in Figure 2A, Trx mediates the flow of electrons from the final donor, reduced NADPH, to target proteins, with Trx reductase as an intermediate step between NADPH and Trx. In the second system (Fig. 2B), oxidized substrates are reduced by Grxs, which are reduced by one (for monothiol Grxs) or two (for dithiol Grxs) GSH moieties at the expense of GSH reductase and NADPH. Several reports describe the existence of cross-talk between both branches of the cellular reducing flow. For instance, it has been reported that human Grx2 can be directly reduced in vitro not only by GSH but also by Trx reductase (48), and the same applies to bacterial Grx4 (26). It has been described that highly abundant GSH can directly reduce oxidized Trx substrates, such as monothiol Prxs $(47,76)$. Regarding the rationale behind the existence of two different cascades to reduce reversible thiols, it is also a matter of study how substrate specificity is achieved. Some studies have suggested that charge complementarity may influence the specificity of redoxins towards their specific substrates $(7,19,33,69)$. Also, the analysis of the crystal structures of mixed disulfides between Trxs and their substrates highlight the importance of structural features around disulfides in proteins to favor recognition by a specific redoxin (63).

Principles for the characterization of the redox status of proteins and proteomes

The study of Cys modifications in proteins and proteomes has been a challenging task until the development of selective reagents and powerful mass spectrometry (MS) techniques and equipment that has occurred during the last decade. Thus, the analysis of Cys-containing peptides through MS is now routinely used to analyze the influence of genetic (i.e. absence of components of thiol reducing systems) or environmental factors (i.e. presence of oxidants, or shift of growth conditions) in general thiol proteome oxidation, but also to determine whether a specific protein participates in a redox cascade. In any case, in order to analyze either at the whole proteome level or at a specific protein 
the reversible oxidation of Cys residues, it is important to take into consideration some principles to obtain protein extracts and isolate peptides suitable to MS analysis (Fig. 3).

The in vivo redox state of thiols can be easily preserved if the reversible modification to be analyzed can be blocked with cell permeable probes, so that the specific labeling reactions can be achieved in intact cells (Fig. 3, left panel). This is the case of trapping reduced thiols (-SH) with permeable alkylating agents such as maleimide derivatives, or sulfenic acid (-SOH) with membrane diffusible dimedone derivatives (see below). Alternatively, the redox state of the cell is mainly preserved by "freezing" thiols and decreasing thiol reactivity with acids such as trichloroacetic acid (TCA) added to cell cultures, which rapidly protonates all redox-active thiolate anions by shifting the $\mathrm{pH}$ below their $\mathrm{pKa}$, and also stops thiol-disulfide exchanges by precipitating and denaturing proteins $(40,59)$. Later on extract preparation, thiol reactive probes (i.e. alkylating agents) can irreversibly attach to newly exposed thiols after gradually increasing the $\mathrm{pH}$ under controlled conditions. This principle applies to the characterization of both proteomes and specific proteins; in the latter case, the redox state of the protein can be analyzed by Western blot, or the protein can be purified with the use of tags or antibodies prior to MS analysis (see below, section 'Electrophoretic and proteomic approaches to study changes in the Cys oxidation state of specific proteins').

Regarding the characterization of reversibly oxidized proteomes, another common principle, although optional, is the enrichment of Cys-containing proteins or peptides (Fig. 3, center panel). This has been traditionally accomplished with the use of chemically modified, most often, biotinylated, tags with reactivity towards reduced thiols [i.e. N-ethylmaleimide (NEM)-biotin (89) or iodoacetamide (IAM)biotin, generally available from ThermoFisherScientific] or oxidized thiols [i.e. dimedone-biotin $(16,78)$ or biotin-1,3-cyclopentanedione, the latter being commercialized by Kerafast]. Affinity purification is then easily accomplished and sample complexity is drastically reduced. To overcome the inconveniences of bulky biotin molecules in MS, in many thiol-reacting agents the biotin moiety can be removed by cleavage after resin enrichment. Another strategy involves the use of specific antibodies, as those that recognize tandem mass tag (TMT)-labeled proteins. Finally, another enrichment strategy makes use of thiol reactive resins that directly capture Cys-containing proteins in its reduced thiol form (see the last paragraph of the section 'Use of Cys-reacting agents to study reversible thiol oxidations - biotin switch, OxICAT, ICAT-MS-based techniques'). 
Because of the particularly dynamic nature of redox proteomes, an important point in their studies is the requirement of quantifying not only modified peptides through MS, but also whole cell extracts (Fig. 3, right panel). The development of isotopic and isobaric labels with reactivity towards thiols has not only been used for sample complexity reduction, but it has also greatly improved the quantitative analysis, as at least six different samples or conditions can be analyzed simultaneously. As important as the quantification of Cys-containing peptides is the comparison of these levels with the total abundance of the corresponding protein in each particular biological sample, since environmental or genetic factors could not only result in increased oxidations but also increased expression levels for a given protein. This is achieved by either labeling proteins with stable isotope labeling by amino acids (SILAC) in cell cultures, or by labeling protein extracts prior to enrichment with amino reactive labels as reported by Garcia-Santamarina and colleagues $(30,32)$.

\section{PROTEOMIC METHODS TO STUDY REVERSIBLE CYS MODIFICATIONS AT THE PROTEOME}

\section{LEVEL}

Most methods to investigate reversible Cys modifications are based on the use of alkylating agents that specifically react with originally oxidized thiol groups (ALK2 in Figure 4A), and after initially reduced thiols have been previously blocked with a different alkylating agent (ALK1 in Figure 4A). These methods can be used for the identification and quantification of oxidized Cys without any information about the nature of the particular reversible oxidation if a generic reducing agent such as dithiothreitol (DTT) is used between both alkylating agents, but can also be adapted to the identification of specific oxidations, based on the specificity of reducing reagents (see the section 'Use of Cys-reacting agents to study reversible thiol oxidations - biotin switch, OxICAT, ICAT-MS-based techniques'). The same chemistry between alkylating agents and sulfhydryl groups has been used to study the propensity of Cys residues to become oxidized (see the section 'Use of Cys-alkylating probes to study Cys reactivity profiling'), or to study the proximity in native protein structures of two Cys residues (see the section 'Thiol-reacting probes to study Cys proximity in native structures'). With the recent development of specific small probes that react selectively with specific oxidized Cys, it is now also possible to identify and quantify specific Cys modifications in complex proteomes, thus 
shortening the whole procedure as the reduction step to obtain free thiols is no longer necessary (see the sections 'Use of reagents specific for sulfenic acid - dimedone and derivatives' and 'Proteomic identification of disulfide-linked peptides'). Figure 4B-to-D summarizes some of the strategies we review in the next five sections. The advantages and limitations of some of the reagents and strategies described below are summarized in Table 1.

Use of Cys-reacting agents to study reversible thiol oxidations - biotin switch, OxICAT, ICAT-MSbased techniques

One of the first strategies designed to study reversibly oxidized thiol proteomes is the biotin switch assay reported by Jaffrey and colleagues (45) with improvements published by the Toledano and Jakob labs such as the use of TCA to freeze the thiol redox status $(57,59)$. Since then, many proteome-wide analyses of thiol redox modifications have been published, but all of them rely on the three steps of this assay (Fig. 4A): first, blocking free thiols with a thiol-specific reacting agent; second, the reduction of oxidized thiols with specific [ascorbate/ $\mathrm{CuCl}_{2}$ for nitrosothiols (44), arsenite for sulfenic acid $(89,109)$ ], or generic [DTT or Tris (2-carboxyethyl) phosphine hydrochloride (TCEP)] thiol reducing reagents; third, labeling of newly generated thiols with a different thiol reactive reagent, normally conjugated with other functional groups that allow the enrichment and quantification of oxidized Cys by either gel-based or gel-free MS.

With the development of the quantitative isotope coded affinity tag (ICAT) technology, based on the reaction of thiol groups with IAM derivatives, a new gel-free strategy was proposed: the OxICAT methodology $(9,35,58)$. According to this approach, the free thiols of one particular biological sample are blocked with the light ICAT reagent, reversibly oxidized Cys are reduced and, finally, nascent thiols are labeled with heavy ICAT. These two reagents contain a thiol reactive moiety, IAM, linked to a biotin tag through a cleavable 9-carbon linker which can be either ${ }^{12} \mathrm{C}\left({ }^{12} \mathrm{C}-\right.$ ICAT $)$ or ${ }^{13} \mathrm{C}$ $\left({ }^{13} \mathrm{C}\right.$-ICAT) therefore differing in $9 \mathrm{Da}$, but being, otherwise, chemically identical. After the MS analysis of enriched peptides, the relative peak areas of the same peptide labeled with light and heavy ICAT reagents reflect its absolute oxidation status. Although a really powerful technique that has been successfully applied to the study of redox proteomes of different organisms $(10,51,67)$, one of the 
main limitations of this approach is its low sensitivity as only $5-10 \%$ of the Cys residues in proteins are in an oxidized state $(31,32)$. However, the sensitivity of OxICAT has improved thanks to technological advances in MS proteomics and data analysis (87).

A new workflow based on the use of ICAT reagents that allows the comparison of two samples at the same time was proposed by several groups, including ours $(25,31,32)$ (Fig. 5). Free thiols are blocked with an alkylating agent in acidic protein extracts, reversibly oxidized Cys are reduced and newly formed thiols are labeled with a light ICAT reagent in one sample and with a heavy ICAT reagent in the other. After sample mixing and trypsin digestion, ICAT-labeled peptides are affinity chromatography-enriched and the biotin tag is removed by acid digestion. Differentially labeled peptides co-elute from the HPLC system and behave equally on the mass spectrometer, with again a difference of $9 \mathrm{Da}$ or multiples of 9 in peptides containing more than one Cys. This strategy can be applied to the identification and quantification of thousands of peptides simultaneously. This approach is more sensitive than the OxICAT as the level of complexity of the sample is considerably reduced because the relative abundances of peptides containing Cys oxidized are similar between samples. Since this method does not distinguish between increased Cys oxidation and increased protein abundance, one additional step is the protein quantification of the non-enriched fractions. This can be accomplished by either label-free or stable isotope-based MS protein quantification of whole cell extracts, trypsinized prior to enrichment (Fig. 5). Examples of the use of the ICAT strategy include its use in the study of protein oxidation in rat hearts subject to ischemia reperfusion (55) or the study of Cys nitrosylation in Arabidopsis plantlets subject to cold stress (81).

Based on the workflow described above, recent variations include the use of other tags with thiol reactivity such as Cys-reacting tandem mass tags (Cys-TMT) that enable the simultaneous identification and multiplexed quantification of thiol redox modifications from up to six different samples. The Cys-TMT reagents are a set of six isobaric compounds with the same nominal mass and chemical structure (i.e., isotopomeric). They are composed of a Cys-reactive dithiopyridine group, a neutral spacer arm or mass normalizer and a mass reporter (126-131Da) which is unique for each of the six reagents. Samples from different experimental conditions are labeled with the different isobaric tags, enriched with a TMT antibody and analyzed by MS/MS. In the first MS, peptides will have the same $\mathrm{m} / \mathrm{z}$ independently of the reagent it has been used. Upon ion fragmentation, the spacer arm is 
cleaved and the resulting reporter ions will differ in their $\mathrm{m} / \mathrm{z}$. The workflow is similar to the scheme described in Figure 5, but, as mentioned, peptides are affinity-enriched with a TMT antibody (70). lodo-TMT reagents, similar to Cys-TMT, are a collection of six isobaric tags in which thiol reactivity is obtained through an IAM group (82). Both types of tags have been used in redox proteomics to specifically identify and quantify nitrosothiol (-SNO) modifications.

After blocking reduced thiols with an alkylating agent and further reduction, it has recently been proposed to capture proteins with originally oxidized thiols directly with a thiol-interacting resin (36). The resin contains thiopropyl sepharose beads with a 2-pyridyl disulfide group, able to react with reduced thiols in extracts to form a reversible mixed disulfide. In this case, digested peptides from onresin digested proteins are labeled at their amino groups with different reagents, such as isobaric tags for relative and absolute quantitation (iTRAQ) or TMTs (not Cys reactive), and analyzed by MS $(29,97,98)$. An interesting application of this workflow is the work by Guo and colleagues (36) that take profit of the availability of several TMT reagents for the simultaneous identification of different Cys oxidations in the same sample. According to this strategy, after blocking free thiols with the alkylating agent NEM, samples are split and each fraction is treated with a specific reducing agent. The free thiols in proteins are enriched by a thiol reactive resin. On the same resin, proteins are digested and peptides are labeled with amino-reacting isobaric reagents. After elution with reducing agents disrupting the mixed disulfides, different samples are mixed and analyzed by MS.

Use of Cys-alkylating probes to study Cys reactivity profiling

The strategy to identify protein targets sensitive to oxidants and establish the reactivity profile of different Cys in proteins is based in measuring the reactivity loss of reduced thiols in proteins. Sethuraman and colleagues first reported the use of the ICAT reagent to measure Cys oxidation in rabbit heart membrane by labeling free thiols in $\mathrm{H}_{2} \mathrm{O}_{2}$-treated and untreated samples. In this case, they quantified the increase in oxidation as a loss in signal for any given pair of light and heavy ICATlabeled peptides corresponding to untreated and treated samples $(92,93)$.

To overcome the problem of thiol labeling by bulky reagents such as ICAT, isotopic tandem orthogonal proteolysis activity-based protein profiling (isoTOP-ABPP) has been designed as an 
alternative approach to study Cys reactivity profiling $(22,110)$. This strategy is based on the development of an IAM-based thiol reactive reagent with a very simple chemical structure. The reagent is functionalized with an alkyne group that allows its conjugation via click chemistry to an azide-functionalized peptide sequence that contains a heavy or light valine and a TEV protease recognition sequence. Finally, this peptide is linked to a biotin moiety for protein enrichment. In the first step, thiols from cell extracts are alkylated with the IAM-derivative to protect them from further oxidation. Then, the copper-catalyzed click chemistry links the isotopic light $\left({ }^{12} \mathrm{C}\right.$ and $\left.{ }^{14} \mathrm{~N}\right)$ and heavy $\left({ }^{13} \mathrm{C}\right.$ and $\left.{ }^{15} \mathrm{~N}\right)$ tags and the cleavable biotin tag to the different samples. Samples are then mixed and subjected to trypsin digestion and TEV protease to yield Cys-containing peptides with isotopic tags for MS proteomic analysis. Differences in the extent of alkylation reflect differences in Cys reactivity, in a way that hyper-reactive Cys would be completely labeled at low probe concentrations while Cys with low reactivity would show a concentration-dependent increase in alkylation.

Recently, an in vivo Cys reactivity profiling study has been performed using permeable Cysreacting agents with mammalian cell cultures (1). Abo and colleagues proposed the use of a permeable electrophile ( $\alpha$-bromomethyl ketone), which is caged to avoid its reaction with cellular proteins; this allows accumulation within cells at high concentration with low toxicity. Cys labeling is triggered in situ using photo-uncaging to unveil the $\alpha$-bromomethyl ketone functional group directly in living cells. In addition, the caged derivative of $\alpha$-bromomethyl ketone also contains an alkyne group to allow the incorporation of reporter tags via click chemistry (1).

Thiol-reacting probes to study Cys proximity in native structures

Vicinal dithiols in proteins are a subset of surface-exposed thiols that are close enough to one another and that are more susceptible to oxidation to a disulfide than isolated thiols. Dithiols can occur through proximity in the primary sequence, typically a -CXnC- motif where " $n$ " is usually in the range of 2-6 residues (34) or close in the tertiary structure of the protein. Dually-Cys reacting probes such as phenylarsine oxide (PAO) have been used to identify vicinal dithiol groups in native proteins $(28,77)$. A proteomic approach to study vicinal dithiols through MS (Fig. 4B) has also been published (83) taking advantage of the dithiol specific probe PAO in a method similar to the biotin switch assay. 
First, PAO is used to selectively block reduced vicinal dithiols. The remaining free thiols in the protein are then alkylated with NEM and cross-linked vicinal dithiols are reverted to the reduced thiol form by reduction with 2,3-dimercapto-1-propanesulfonic acid and subsequently labeled with a thiol reactive reagent either conjugated to biotin or to Сy5/Сy3 maleimide. This approach was used for the identification of vicinal dithiols in mitochondria (83). A biotin conjugated PAO probe was used to enrich arsenic binding proteins in the MCF7 cell line (120).

Use of reagents specific for sulfenic acid - dimedone and derivatives

Cys sulfenic acid is difficult to detect because of its highly unstable nature, but at the same time since it can act as a nucleophile and an electrophile depending on the surrounding environment, it has been easy to develop probes for its detection in proteins. One of the most extensively used probes to investigate S-sulfenylated proteins is the nucleophile 5,5-dimethyl-1,3-cyclohexadione (dimedone) (Fig. 4C). Improved alkyne and azide analogs of dimedone have been recently developed as, on one hand, they are cell permeable and enable in situ labeling and, on the other hand, S-sulfenylated proteins can be captured through conjugating via click chemistry appropriate tags into modified proteins $(2,53,60,75)$. In a new workflow using isotope coded alkynyl functionalized dimedone, DYn-2, the Carroll group has identified and quantified specific sulfenylated Cys in proteomes. S-sulfenylated proteins are specifically labeled with DYn-2 in intact cells. Proteins are then digested and conjugated to azide biotin, affinity purified and released of the photo-cleavable biotin linker. Modified and enriched peptides are then analyzed through MS $(117,118)$. Alternatively, dimedone-containing proteins can be captured using specific anti-dimedone antibodies such as the ones developed by the Eaton (64) and Carroll (91) labs .

\section{Proteomic identification of disulfide-linked peptides}

The direct identification of protein disulfides in a protein extract is difficult as there are no specific probes for this modification. Regarding intra-or inter-protein disulfides, a two-dimensional diagonal denaturing gel-based strategy has been adapted to identify cytoplasmic proteins with disulfide bonds 
(14) (Fig. 4D). In the first dimension of the electrophoresis, proteins are separated under nonreducing conditions. The lane containing separated proteins is excised and placed horizontally on a second gel. This second electrophoresis is performed under reducing conditions. The resulting diagonal line of proteins represents those proteins without disulfide bonds. The spots that appear on the right side of the diagonal are proteins forming inter-molecular disulfides and spots on the left side of the diagonal are those forming intra-molecular cross-links.

Regarding the direct identification of intra and inter-molecular disulfides in proteomes through MS, recent advances in MS technology and software are very promising. Lu and colleagues (62) have reported the design of a new software, pLink-SS, an adaptation of a previous program used for the identification of cross-linked proteins [pLink; (116)]. pLink-SS is specific for the identification of disulfide cross-links in different types of complex samples. Other software used for the MS identification of cross-linked peptides, such as Kojak (42), has not yet been applied specifically to redox proteomics, as far as we know.

Disulfide bonds can also occur in the form of mixed disulfides with GSH (PrS-SG), and those can be analyzed after the alkylation of free reduced thiols using Grx as a reducing agent (97). Direct methods for studying this kind of modification make use of permeable biotinylated GSH or GSSG directly added to the cells resulting in a thiol-disulfide exchange. In this way, S-glutathionylated proteins are labeled with biotin and can be affinity purified and analyzed through MS $(15,119)$. A recent improvement of this approach is the use of a GSH derivative with small clickable functionality instead of bulky biotin (88). This clickable GSH is conjugated in situ to cell proteins and Sglutathionylated proteins can be further conjugated to other chemical groups in order to be detected. However, this new approach has not yet been applied to MS-based proteomics.

\section{ELECTROPHORETIC AND PROTEOMIC APPROACHES TO STUDY CHANGES IN THE CYS OXIDATION STATE OF SPECIFIC PROTEINS}

$\mathrm{H}_{2} \mathrm{O}_{2}$ participates in the regulation of signaling pathways through the specific, fast and reversible oxidation of amino acid residues in sensor proteins. As widely explained in the Introduction, Cys residues are susceptible to reversible and irreversible oxidation upon $\mathrm{H}_{2} \mathrm{O}_{2}$ fluctuations $(46,74,112)$. 
Other amino acids such as methionine, tyrosine or tryptophan are prone to oxidation by $\mathrm{H}_{2} \mathrm{O}_{2}$, but the impact of those events in signaling cascades is, at best, not widespread.

As explained above, factors other than pKa define the reaction rates of specific Cys residues in proteins towards peroxides, and, despite the fact that bioinformatic tools exist to predict Cys reactivity (95), currently real thiol switches can only be demonstrated experimentally. In the first section below ('Analyzing redox switches in specific proteins using denaturing polyacrylamide gel electrophoresis'), we will provide some examples of electrophoretic-based techniques used for the confirmation of a reversible thiol switch in a specific protein. We will then describe, using the bona fide protein sensors of $\mathrm{H}_{2} \mathrm{O}_{2}$ as examples, some MS-based approaches to identify the specific Cys residues suffering these reversible redox post-transcriptional modifications (see the section 'MS-based characterization of specific reversible Cys oxidations in classical $\mathrm{H}_{2} \mathrm{O}_{2}$ sensors'). Lastly, we will summarize some protocols, based on MS, to identify unknown components in redox signaling cascades, using upstream or downstream protein components as baits (see the section 'MS-based identification of redox signaling components').

Analyzing redox switches in specific proteins using denaturing polyacrylamide gel electrophoresis

To demonstrate that a protein contains a thiol switch, that is, a Cys residue susceptible of reversible oxidant-dependent oxidation, many biochemical approaches have been designed, most based on the use of denaturing polyacrylamide gel electrophoresis (SDS-PAGE) followed by Western blot with antibodies against the protein of interest.

In those methods, the general principles for the preparation of whole cell extracts apply (see the section 'Principles for the characterization of the redox status of proteins and proteomes'). Briefly, the in vivo redox status of thiols in cell cultures is frozen through acidification with TCA followed by preparation of whole cell extracts. After this point, at least five different approaches have been reported to demonstrate a thiol switch (Fig. 6).

The first approach, which was proposed by our group in 2011 (32), can be applied to any given protein and does not rely on an electrophoretic mobility shift of the protein of interest upon thiol oxidation (Fig. 6A). After cell culture acidification with TCA, the blockage of free thiols with IAM and 
reduction of reversibly oxidized thiols with DTT or TCEP, originally oxidized thiols are biotin-labeled with the reversible thiol reagent $N$-[6-(Biotinamido)hexyl]-3'-(2'-pyridyldithio)propionamide (biotinHPDP). Each step in the alkylation and reduction procedures is stopped by TCA precipitation (32). All proteins containing reversibly oxidized thiols are then affinity-purified with avidin beads, eluted with a thiol reducing agent and detected by standard SDS-PAGE followed by Western blot. We successfully used this method to confirm thiol oxidation of specific protein targets identified at the proteome level after $\mathrm{H}_{2} \mathrm{O}_{2}$ stress in S. pombe (32).

Quite often the generation of intra-molecular disulfide bonds changes the compactness degree for a given protein, and those differential structural changes can be highlighted using non-reducing SDS-PAGE of whole cell extracts (Fig. 6B). This is the case of the S. pombe Pap1 transcription factor, which becomes oxidized upon mild oxidative stress (107). The structural changes in Pap1 as a result of one or two intra-molecular disulfides can be detected as the oxidized protein migrates faster in non-reducing SDS-PAGE.

Nevertheless, not all proteins with $\mathrm{H}_{2} \mathrm{O}_{2}$-dependent intra-molecular disulfides suffer a conformational change suitable to be detected by standard SDS-PAGE. The bacterial $\mathrm{H}_{2} \mathrm{O}_{2}$ sensor OxyR is an example of this. Two strategies have been used to differentiate reduced and oxidized OxyR. First, the use of a urea-containing gel matrix for electrophoresis (99). Second, the use of a bulky alkylating agent, such as 4-acetamido-4'-maleimidylstilbene-2,2'-disulfonic acid (AMS), with a net molecular weight of $\sim 0.5 \mathrm{KDa}$ (Fig. 6C) (4).

Finally, inter-molecular disulfides formed upon $\mathrm{H}_{2} \mathrm{O}_{2}$ treatment are often present in representatives of the Prx and Gpx families. Then, the covalent dimerization after oxidant treatment can be highlighted under non-reducing SDS-PAGE, with an apparent shift of mass equivalent to two monomers (Fig. 6D). As an example, the 2-Cys Prx Tpx1 from S. pombe forming a dimer between two anti-parallel Tpx1 monomers arranged head to tail during $\mathrm{H}_{2} \mathrm{O}_{2}$ scavenging (12).

MS-based characterization of specific reversible Cys oxidations in classical $\mathrm{H}_{2} \mathrm{O}_{2}$ sensors

Within this section, we do not pretend to display a catwalk of all redox dependent proteins or pathways. We will only review the pioneer studies on few classical redox-sensing transcription factors 
and/or $\mathrm{H}_{2} \mathrm{O}_{2}$ sensors (bacterial OxyR, and the eukaryotic couples Gpx3-Yap1 and Tpx1-Pap1), and how their specific thiol switches have been unambiguously characterized through MS. As will be outlined in the three examples provided, genetic studies with Cys mutant proteins normally precede MS studies, or are later used to confirm the MS-based results.

The Escherichia coli transcription factor OxyR was the first $\mathrm{H}_{2} \mathrm{O}_{2}$ sensor identified and characterized at the genetic and biochemical level (Fig. 7A). Oxidation by peroxides of Cys199 to a sulfenic acid precedes the formation of a disulfide bond with Cys208, leading to a conformational change and a gain-of-function in the transcription factor, to trigger antioxidant response genes. Reduced OxyR is pre-bound to some of its target promoters as a tetramer, but it does not stimulate transcription until disulfide formation occurs $(101,121)$. OxyR responds to different oxidants. For instance, it has been proposed that reactive nitrogen species can activate OxyR through Snitrosylating Cys199 (50).

OxyR has six Cys residues. The Storz group demonstrated through mutational studies that only two of them are critical for transcriptional activity (54). They performed an MS analysis of an OxyR derivative (OxyR4C $\rightarrow A$ ) carrying Ala substitutions of the other four non-essential Cys (121). Reduced and oxidized OxyR4C $\rightarrow \mathrm{A}$ after alkylation with IAM and trypsin digestion were examined through matrix-assisted laser desorption/ionization-time-of-flight (MALDI-TOF) MS. Two peaks corresponding to fragments containing alkylated Cys199 and Cys208 for the reduced proteins disappeared in the oxidized samples. A new peak appeared in the oxidized samples corresponding to the disulfide bond linking peptides containing Cys199 and Cys208 (121). This pioneer work on the first thiol switch, OxyR, was performed with purified proteins; reduced OxyR was processed for MS in an anaerobic chamber (121).

In budding yeast, the basic-leucine zipper (bZIP) transcription factor Yap1 is the functional homolog of OxyR. Genetic studies suggested that Yap1 is oxidized upon $\mathrm{H}_{2} \mathrm{O}_{2}$ exposure, so that an intra-molecular disulfide bond between Cys303 and Cys598 is formed (20). As a result, Yap1's nuclear export signal (NES) is hindered, and the transcription factor accumulates at the nucleus $(52,114,115)$. Using purified Yap1 protein, Wood and colleagues identified through MS two intramolecular disulfide bonds between Cys303-Cys598 and Cys310-Cys629; those MS peaks were DTTsensitive (113). However, it was later described that Yap1 is not directly oxidized by $\mathrm{H}_{2} \mathrm{O}_{2}$, but it is 
rather regulated by a thiol-disulfide exchange reaction with an upstream $\mathrm{H}_{2} \mathrm{O}_{2}$ sensor: the $\mathrm{Gpx} \mathrm{Gpx} 3$ (21) (Fig. 7B). As will be explained in the next section ('MS-based identification of redox signaling components'), the authors identified this upstream redox driver through MS using Yap1 as bait. Regarding the individual components of this redox relay, Gpx3 and Yap1, no MS-based studies have been published to confirm the in vivo redox state of their thiol switches.

The S. pombe Pap1 transcription factor is the fission yeast homolog of Yap1 (Fig. 7C). Pap1 contains seven Cys residues clustered in two domains, one at the center of the polypeptide called the $\mathrm{N}$-terminal Cys rich domain and the second at the carboxyl-terminal domain. Using recombinant domains of Pap1, it was soon reported using MS that peptides containing some Cys residues were susceptible to being modified by alkylating agents (13). Genetic analysis using S. pombe strains expressing Cys mutants also highlighted the requirement of two of those residues, Cys278 and Cys501, in the response to $\mathrm{H}_{2} \mathrm{O}_{2}$ (107). However, it was not until 2013 when our group unambiguously reported the participation of four Cys residues in the response to peroxides, using a combination of genetic and MS-based experiments (11). Regarding the proteomic characterization of the protein, following the pipeline described in Figure 4A we obtained acidic cell extracts from cultures untreated or treated with $\mathrm{H}_{2} \mathrm{O}_{2}$; reduced thiols were alkylated with $\mathrm{NEM}$; then, reversibly oxidized thiols were reduced with TCEP and the resulting new thiols were alkylated with IAM. Denatured samples were then dialyzed and hemagglutinin (HA)-Pap1 was affinity purified with anti-HA. The immunoprecipitates were loaded onto standard SDS-PAGE gels, and gel slices corresponding to tagged Pap1 were trypsinized and analyzed through MS (11). The results demonstrated that four Cys residues, Cys278, 285, 501 and 532, were alkylated with IAM only when the protein was purified from $\mathrm{H}_{2} \mathrm{O}_{2}-$ treated cultures (11).

As shown above for Yap1, the transcription factor Pap1 is not the direct sensor of $\mathrm{H}_{2} \mathrm{O}_{2}$. Indeed, the peroxiredoxin Tpx1, with exquisite sensitivity for peroxides, is the real sensor towards Pap1 under mild oxidative stress $(8,106)$ (Fig. $7 \mathrm{C}$ ), and the main scavenger of $\mathrm{H}_{2} \mathrm{O}_{2}$ during aerobic metabolism in fission yeast (47). Tpx1 peroxidase function is based on two redox-active Cys, Cys48 and Cys169.

MS-based identification of new redox signaling components 
We will now review some published examples in which new components of redox cascades were identified through MS using known proteins of the pathway as baits. Regarding cell lysis and extract preparation, most of the rules we have proposed for maintaining the in vivo redox state of Cys residues (see section in the Introduction: 'Principles for the characterization of the redox status of proteins and proteomes') also apply to the co-immuno-purification procedures described here (Fig. 3). However, it is worth mentioning that often these redox cascades are governed by thiol disulfide exchanges, so that the interactions between two different components are mediated by very transient mixed disulfide intermediates. Two common strategies have been proposed to trap this transient intermediates: first, the use of short exposures or pulses of extracellular peroxides, followed by the fast acidification or addition of permeable alkylating agents such as NEM or methyl methanethiosulfonate (MMTS); second, the use of "trapping mutants" as baits: if the downstream receiver of the redox signal, used as bait, does not contain the Cys residue known to resolve the mixed disulfide, the transient intermediate will be stabilized. We will now briefly review co-immuno precipitation examples using one or both of these strategies: the MS-based identification of upstream components of the Yap1 (21), Pap1 (12) and thioredoxin cascades $(12,30)$, and of the downstream redox interactors of FOXO3 (80) and mammalian Prx2 (94) proteins.

As explained above, the peroxidase $\mathrm{Gpx} 3$ is the real $\mathrm{H}_{2} \mathrm{O}_{2}$ sensor promoting the oxidation of the Yap1 transcription factor (Fig. 7B). Using the general principles applied to the preservation of the in vivo redox state of Cys residues, Gpx3 was identified by MS after immuno-precipitating a trapping Yap1 mutant lacking Cys303, which resolves the mixed disulfide in the transient intermediate between both proteins (21). Briefly, Delaunay and colleagues purified the Myc-Yap1.C303A mutant from TCA extracts of $\mathrm{H}_{2} \mathrm{O}_{2}$-treated cultures through affinity chromatography, resolved the eluted proteins through non-reducing SDS-PAGE and detected a high molecular weight mixed-disulfide partner. Gel slices were trypsinized and analyzed through nanoscale capillary liquid chromatography-tandem MS (LCMS/MS). Using this approach, the authors not only identified peptides belonging to Gpx3 but also a covalently-linked peptide between the 598-604 amino acids of Yap1 and 36-43 amino acids of Gpx3, confirming the mixed disulfide between Cys36 of Gpx3 and Cys598 of Yap1. 
Regarding the fission yeast redox couple Tpx1/Pap1, even though it was soon reported by genetic and biochemical means that the Prx is the real receptor of $\mathrm{H}_{2} \mathrm{O}_{2}$ and that in its absence Pap1 is not oxidized upon peroxide stress, trapping an intermediate between both proteins and identifying Tpx1 through MS using Pap1 as bait has been a difficult task. In 2013, Calvo and colleagues managed to detect Tpx1 in co-immuno precipitates of HA-Pap1, which was over-expressed in cells lacking the main thioredoxin, $\operatorname{Tr} 1$ (to decrease the turnover of the oxidation process) (12). With this approach, we initially detected a high-molecular-weight complex, sensitive to disulfide reducing agents, recognized both with anti-Pap1 and also with anti-Tpx1 antibodies through Western blot analysis. To confirm the disulfide-linked Tpx1-Pap1 intermediate, TCA protein extracts were dialyzed and immuno-precipitated with anti-HA antibodies. The band corresponding to the mixed disulfide was excised from a gel, trypsinized and processed for MS analysis. The most abundant proteins present in the gel slice detected through liquid LC-MS/MS were Tpx1 and Pap1 with a coverage of $61 \%$ and $42 \%$, respectively (12).

Another example of the use of a downstream component of redox cascades as bait to isolate a new (and oxidizing) redox partner is the identification of Trx substrates. As happens with Yap1 and Pap1 in the two examples provided above (Gpx3/Yap1 and Tpx1/Pap1), Trxs are the electron donors of their substrates, and reduce disulfides by forming transient intermediates with them. As described in the Introduction, Trxs mediate the electron flow of electrons from the final donor, reduced NADPH, to disulfide-containing substrates. The Trx fold, which contains the sequence Cys-X-X-Cys, present in Trxs, mediates the interaction with their substrates: while the first Cys forms the transient intermediate with one of the substrate Cys residues, the second Cys of the Trx folds resolves the mixed disulfide. Many studies have reported the MS-based identification of putative Trx substrates using mutant Trxs lacking the second (or resolving) Cys as bait $(5,41,71,96)$.

Forkhead box $\mathrm{O}$ (FOXO) transcription factors are considered key players in redox signaling. Their activity is modulated by ROS-induced post-transcriptional modifications $(3,18)$, leading to their nuclear accumulation in a Jun kinase-dependent manner $(24,72)$. Putker and colleagues described the identification of several ROS-induced, disulfide-linked FOXO4 (79) and FOXO3 (80) partners. Regarding FOXO4, in order to focus on disulfide-linked associations the authors immuno-precipitated a mutant FOXO4 lacking all Cys residues as a control. Furthermore, the authors also separated the 
FOXO4 and the FOXO4 $\triangle$ Cys negative control pull downs through non reducing SDS-PAGE, and identified the DTT-sensitive complexes through MS (79).

Finally, another example describing the isolation of downstream components of $\mathrm{H}_{2} \mathrm{O}_{2}$ responding pathways is the recent work by Sobotta and colleagues (94). As explained in the Introduction, Gpxs and Prxs are suited to sense $\mathrm{H}_{2} \mathrm{O}_{2}$, scavenging it and also directing oxidative equivalents to specific target proteins by direct thiol disulfide exchanges, as described in budding and fission yeast (Gpx3-to-Yap1 and Tpx1-to-Pap1) $(8,21,106)$. Using mammalian Prx2 as bait, the Dick group has recently described that this type of redox relay also applies to the mammalian couple Prx2STAT3 transcription factor. To trap the very transient intermediate between Prx2 and its downstream effectors, the authors used very short pulses of exogenous $\mathrm{H}_{2} \mathrm{O}_{2}$ followed by the blockade of free thiols directly in cultures with NEM or methyl MMTS (94).

\section{CONCLUSIONS}

While Cys post-transcriptional modification by oxidants has been reported in many studies of either toxicity or signaling associated to oxidative stress, the development and widespread use of powerful MS-based techniques linked to basic redox principles in sample manipulation and preparation is greatly contributing to clarifying the role of ROS fluctuations in health and disease. With this review, we have intended to provide advice on the MS-based detection, identification and quantification of reversible Cys oxidations in entire proteomes, as well as in signal transduction-related thiol switches of proteins such as Prxs or OxyR. 


\section{ACKNOWLEDGEMENTS}

This work was supported by the Spanish Ministry of Science and Innovation (BFU2012-32045), PLAN E and FEDER, and by 2014-SGR-154 from Generalitat de Catalunya (Spain) to E.H. A.D. is recipient of a predoctoral fellowship from Generalitat de Catalunya (Spain). E.H. is recipient of an ICREA Academia Award (Generalitat de Catalunya, Spain).

Author Disclosure Statement: No competing financial interests exist 


\section{LIST OF ABBREVIATIONS}

bZIP: basic leucine zipper

Cys: cysteine

Cys-TMT: cysteine tandem mass tag

DTT: dithiothreitol

Gpx: glutathione peroxidase

Grx: glutaredoxin

GSH: glutathione

$\mathrm{H}_{2} \mathrm{O}_{2}$ : hydrogen peroxide

IAM: iodoacetamide

ICAT: quantitative isotope coded affinity tag

LC-MS/MS: liquid chromatography followed by tandem MS

MALDI-TOF: matrix-assisted laser desorption/ionization time-of-fly

MMTS: methyl methanothiosulphonate

MS: mass spectrometry

NADPH: nicotinamide adenine dinucleotide phosphate

NEM: N-ethyl maleimide

Prx: peroxiredoxin

ROS: reactive oxygen species

TMT: tandem mass tag

SDS-PAGE: sodium dodecyl sulphate polyacrylamide gel electrophoresis

TCA: trichloroacetic acid

TCEP: Tris (2-carboxyethyl) phosphine hydrochloride

Trx: thioredoxin 


\section{REFERENCES}

1. Abo M, Weerapana E. A Caged Electrophilic Probe for Global Analysis of Cysteine Reactivity in Living Cells. J Am Chem Soc 137: 7087-90, 2015.

2. Akter S, Huang J, Bodra N, De Smet B, Wahni K, Rombaut D, Pauwels J, Gevaert K, Carroll K, Van Breusegem F, Messens J. DYn-2 Based Identification of Arabidopsis Sulfenomes. Mol Cell Proteomics 14: 1183-200, 2015.

3. Anderson MJ, Viars CS, Czekay S, Cavenee WK, Arden KC. Cloning and characterization of three human forkhead genes that comprise an FKHR-like gene subfamily. Genomics 47: 18799, 1998.

4. Aslund F, Zheng M, Beckwith J, Storz G. Regulation of the OxyR transcription factor by hydrogen peroxide and the cellular thiol-disulfide status. Proc Natl Acad Sci U S A 96: 6161-5, 1999.

5. Balmer Y, Koller A, del Val G, Manieri W, Schurmann P, Buchanan BB. Proteomics gives insight into the regulatory function of chloroplast thioredoxins. Proc Natl Acad Sci U S A 100: 370-5, 2003.

6. Baty JW, Hampton MB, Winterbourn CC. Proteomic detection of hydrogen peroxide-sensitive thiol proteins in Jurkat cells. Biochem J 389: 785-95, 2005.

7. Berndt C, Schwenn J-D, Lillig CH. The specificity of thioredoxins and glutaredoxins is determined by electrostatic and geometric complementarity. Chem Sci 6: 7049-7058, 2015.

8. Bozonet SM, Findlay VJ, Day AM, Cameron J, Veal EA, Morgan BA. Oxidation of a eukaryotic 2-Cys peroxiredoxin is a molecular switch controlling the transcriptional response to increasing levels of hydrogen peroxide. J Biol Chem 280: 23319-27, 2005.

9. Brandes N, Reichmann D, Tienson H, Leichert LI, Jakob U. Using quantitative redox proteomics to dissect the yeast redoxome. J Biol Chem 286: 41893-903, 2011.

10. Brandes N, Tienson H, Lindemann A, Vitvitsky V, Reichmann D, Banerjee R, Jakob U. Time line of redox events in aging postmitotic cells. Elife 2: e00306, 2013.

11. Calvo IA, Ayte J, Hidalgo E. Reversible thiol oxidation in the H2O2-dependent activation of the transcription factor Pap1. J Cell Sci 126: 2279-84, 2013.

12. Calvo IA, Boronat S, Domenech A, Garcia-Santamarina S, Ayte J, Hidalgo E. Dissection of a redox relay: $\mathrm{H} 2 \mathrm{O} 2-d e p e n d e n t$ activation of the transcription factor Pap1 through the peroxidatic Tpx1-thioredoxin cycle. Cell Rep 5: 1413-24, 2013.

13. Castillo EA, Ayte J, Chiva C, Moldon A, Carrascal M, Abian J, Jones N, Hidalgo E. Diethylmaleate activates the transcription factor Pap1 by covalent modification of critical cysteine residues. Mol Microbiol 45: 243-54, 2002.

14. Cumming RC, Andon NL, Haynes PA, Park M, Fischer WH, Schubert D. Protein disulfide bond formation in the cytoplasm during oxidative stress. J Biol Chem 279: 21749-58, 2004.

15. Chardonnet S, Sakr S, Cassier-Chauvat C, Le Marechal P, Chauvat F, Lemaire SD, Decottignies P. First proteomic study of S-glutathionylation in cyanobacteria. J Proteome Res 14: 59-71, 2015.

16. Charles RL, Schroder E, May G, Free P, Gaffney PR, Wait R, Begum S, Heads RJ, Eaton P. Protein sulfenation as a redox sensor: proteomics studies using a novel biotinylated dimedone analogue. Mol Cell Proteomics 6: 1473-84, 2007.

17. D'Autreaux B, Toledano MB. ROS as signalling molecules: mechanisms that generate specificity in ROS homeostasis. Nat Rev Mol Cell Biol 8: 813-24, 2007.

18. de Keizer PL, Burgering BM, Dansen TB. Forkhead box 0 as a sensor, mediator, and regulator of redox signaling. Antioxid Redox Signal 14: 1093-106, 2011.

19. de Lamotte-Guery F, Miginiac-Maslow M, Decottignies P, Stein M, Minard P, Jacquot JP. Mutation of a negatively charged amino acid in thioredoxin modifies its reactivity with chloroplastic enzymes. Eur J Biochem 196: 287-94, 1991.

20. Delaunay $A$, Isnard $A D$, Toledano $M B$. $H(2) O(2)$ sensing through oxidation of the Yap1 transcription factor. EMBO J. 19: 5157-5166, 2000.

21. Delaunay A, Pflieger D, Barrault MB, Vinh J, Toledano MB. A thiol peroxidase is an $\mathrm{h}(2) \mathrm{o}(2)$ receptor and redox-transducer in gene activation. Cell 111: 471-481, 2002.

22. Deng X, Weerapana E, Ulanovskaya O, Sun F, Liang H, Ji Q, Ye Y, Fu Y, Zhou L, Li J, Zhang H, Wang C, Alvarez S, Hicks LM, Lan L, Wu M, Cravatt BF, He C. Proteome-wide 
quantification and characterization of oxidation-sensitive cysteines in pathogenic bacteria. Cell Host Microbe 13: 358-70, 2013.

23. Denu JM, Tanner KG. Specific and reversible inactivation of protein tyrosine phosphatases by hydrogen peroxide: evidence for a sulfenic acid intermediate and implications for redox regulation. Biochemistry 37: 5633-42, 1998.

24. Essers MA, Weijzen S, de Vries-Smits AM, Saarloos I, de Ruiter ND, Bos JL, Burgering BM. FOXO transcription factor activation by oxidative stress mediated by the small GTPase Ral and JNK. EMBO J 23: 4802-12, 2004.

25. Fares A, Rossignol M, Peltier JB. Proteomics investigation of endogenous S-nitrosylation in Arabidopsis. Biochem Biophys Res Commun 416: 331-6, 2011.

26. Fernandes AP, Fladvad M, Berndt $C$, Andresen $C$, Lillig $C H$, Neubauer $P$, Sunnerhagen $M$, Holmgren A, Vlamis-Gardikas A. A novel monothiol glutaredoxin (Grx4) from Escherichia coli can serve as a substrate for thioredoxin reductase. J Biol Chem 280: 24544-52, 2005.

27. Ferrer-Sueta G, Manta B, Botti H, Radi R, Trujillo M, Denicola A. Factors affecting protein thiol reactivity and specificity in peroxide reduction. Chem Res Toxicol 24: 434-50, 2011.

28. Foley TD, Stredny CM, Coppa TM, Gubbiotti MA. An improved phenylarsine oxide-affinity method identifies triose phosphate isomerase as a candidate redox receptor protein. Neurochem Res 35: 306-14, 2010.

29. Forrester MT, Thompson JW, Foster MW, Nogueira L, Moseley MA, Stamler JS. Proteomic analysis of S-nitrosylation and denitrosylation by resin-assisted capture. Nat Biotechnol 27: 557-9, 2009.

30. Garcia-Santamarina S, Boronat S, Calvo IA, Rodriguez-Gabriel M, Ayte J, Molina H, Hidalgo E. Is oxidized thioredoxin a major trigger for cysteine oxidation? Clues from a redox proteomics approach. Antioxid Redox Signal 18: 1549-56, 2013.

31. Garcia-Santamarina S, Boronat S, Domenech A, Ayte J, Molina H, Hidalgo E. Monitoring in vivo reversible cysteine oxidation in proteins using ICAT and mass spectrometry. Nat Protoc 9: 1131-45, 2014.

32. Garcia-Santamarina S, Boronat S, Espadas G, Ayte J, Molina H, Hidalgo E. The oxidized thiol proteome in fission yeast--optimization of an ICAT-based method to identify H2O2-oxidized proteins. J Proteomics 74: 2476-86, 2011.

33. Geck MK, Larimer FW, Hartman FC. Identification of residues of spinach thioredoxin $f$ that influence interactions with target enzymes. J Biol Chem 271: 24736-40, 1996.

34. Gitler C, Zarmi B, Kalef E. General method to identify and enrich vicinal thiol proteins present in intact cells in the oxidized, disulfide state. Anal Biochem 252: 48-55, 1997.

35. Go YM, Roede JR, Walker DI, Duong DM, Seyfried NT, Orr M, Liang Y, Pennell KD, Jones DP. Selective targeting of the cysteine proteome by thioredoxin and glutathione redox systems. Mol Cell Proteomics 12: 3285-96, 2013.

36. Guo J, Gaffrey MJ, Su D, Liu T, Camp DG, 2nd, Smith RD, Qian WJ. Resin-assisted enrichment of thiols as a general strategy for proteomic profiling of cysteine-based reversible modifications. Nat Protoc 9: 64-75, 2014.

37. Hall A, Karplus PA, Poole LB. Typical 2-Cys peroxiredoxins--structures, mechanisms and functions. FEBS J 276: 2469-77, 2009.

38. Hall A, Nelson K, Poole LB, Karplus PA. Structure-based insights into the catalytic power and conformational dexterity of peroxiredoxins. Antioxid Redox Signal 15: 795-815, 2011.

39. Halliwell B. Reactive species and antioxidants. Redox biology is a fundamental theme of aerobic life. Plant Physiol 141: 312-22, 2006.

40. Held JM, Gibson BW. Regulatory control or oxidative damage? Proteomic approaches to interrogate the role of cysteine oxidation status in biological processes. Mol Cell Proteomics 11: R111 013037, 2012.

41. Hisabori T, Hara S, Fujii T, Yamazaki D, Hosoya-Matsuda N, Motohashi K. Thioredoxin affinity chromatography: a useful method for further understanding the thioredoxin network. J Exp Bot 56: 1463-8, 2005.

42. Hoopmann MR, Zelter A, Johnson RS, Riffle M, MacCoss MJ, Davis TN, Moritz RL. Kojak: efficient analysis of chemically cross-linked protein complexes. J Proteome Res 14: 2190-8, 2015.

43. Imlay JA, Fridovich I. Assay of metabolic superoxide production in Escherichia coli. J Biol Chem 266: 6957-65, 1991. 
44. Jaffrey SR, Erdjument-Bromage H, Ferris CD, Tempst P, Snyder SH. Protein S-nitrosylation: a physiological signal for neuronal nitric oxide. Nat Cell Biol 3: 193-7, 2001.

45. Jaffrey SR, Snyder SH. The biotin switch method for the detection of S-nitrosylated proteins. SCi STKE 2001: pl1, 2001.

46. Janssen-Heininger YM, Mossman BT, Heintz NH, Forman HJ, Kalyanaraman B, Finkel T, Stamler JS, Rhee SG, van der Vliet A. Redox-based regulation of signal transduction: principles, pitfalls, and promises. Free Radic Biol Med 45: 1-17, 2008.

47. Jara M, Vivancos AP, Calvo IA, Moldon A, Sanso M, Hidalgo E. The peroxiredoxin Tpx1 is essential as a $\mathrm{H} 2 \mathrm{O} 2$ scavenger during aerobic growth in fission yeast. Mol Biol Cell 18: 228895, 2007.

48. Johansson $\mathrm{C}$, Lillig $\mathrm{CH}$, Holmgren A. Human mitochondrial glutaredoxin reduces Sglutathionylated proteins with high affinity accepting electrons from either glutathione or thioredoxin reductase. J Biol Chem 279: 7537-43, 2004.

49. Kemp M, Go YM, Jones DP. Nonequilibrium thermodynamics of thiol/disulfide redox systems: a perspective on redox systems biology. Free Radic Biol Med 44: 921-37, 2008.

50. Kim SO, Merchant K, Nudelman R, Beyer WF, Jr., Keng T, DeAngelo J, Hausladen A, Stamler JS. OxyR: a molecular code for redox-related signaling. Cell 109: 383-396, 2002.

51. Knoefler D, Thamsen M, Koniczek M, Niemuth NJ, Diederich AK, Jakob U. Quantitative in vivo redox sensors uncover oxidative stress as an early event in life. Mol Cell 47: 767-76, 2012.

52. Kuge S, Toda T, lizuka N, Nomoto A. Crm1 (Xpol) dependent nuclear export of the budding yeast transcription factor yAP-1 is sensitive to oxidative stress. Genes Cells 3: 521-532, 1998.

53. Kulathu Y, Garcia FJ, Mevissen TE, Busch M, Arnaudo N, Carroll KS, Barford D, Komander D. Regulation of $\mathrm{A} 20$ and other OTU deubiquitinases by reversible oxidation. Nat Commun 4: 1569, 2013.

54. Kullik I, Toledano MB, Tartaglia LA, Storz G. Mutational analysis of the redox-sensitive transcriptional regulator OxyR: regions important for oxidation and transcriptional activation. J.Bacteriol. 177: 1275-1284, 1995.

55. Kumar V, Kleffmann T, Hampton MB, Cannell MB, Winterbourn CC. Redox proteomics of thiol proteins in mouse heart during ischemia/reperfusion using ICAT reagents and mass spectrometry. Free Radic Biol Med 58: 109-17, 2013.

56. Lambeth JD. NOX enzymes and the biology of reactive oxygen. Nat Rev Immunol 4: 181-9, 2004.

57. Le Moan N, Clement G, Le Maout S, Tacnet F, Toledano MB. The Saccharomyces cerevisiae proteome of oxidized protein thiols: contrasted functions for the thioredoxin and glutathione pathways. J Biol Chem 281: 10420-30, 2006.

58. Leichert LI, Gehrke F, Gudiseva HV, Blackwell T, Ilbert M, Walker AK, Strahler JR, Andrews PC, Jakob U. Quantifying changes in the thiol redox proteome upon oxidative stress in vivo. Proc Natl Acad Sci U S A 105: 8197-202, 2008.

59. Leichert LI, Jakob U. Protein thiol modifications visualized in vivo. PLoS Biol 2: e333, 2004.

60. Leonard SE, Reddie KG, Carroll KS. Mining the thiol proteome for sulfenic acid modifications reveals new targets for oxidation in cells. ACS Chem Biol 4: 783-99, 2009.

61. Li S, Tan HY, Wang N, Zhang ZJ, Lao L, Wong CW, Feng Y. The Role of Oxidative Stress and Antioxidants in Liver Diseases. Int J Mol Sci 16: 26087-124, 2015.

62. Lu S, Fan SB, Yang B, Li YX, Meng JM, Wu L, Li P, Zhang K, Zhang MJ, Fu Y, Luo J, Sun RX, He SM, Dong MQ. Mapping native disulfide bonds at a proteome scale. Nat Methods 12: 329-31, 2015.

63. Maeda K, Hagglund P, Finnie C, Svensson B, Henriksen A. Structural basis for target protein recognition by the protein disulfide reductase thioredoxin. Structure 14: 1701-10, 2006.

64. Maller C, Schroder E, Eaton P. Glyceraldehyde 3-phosphate dehydrogenase is unlikely to mediate hydrogen peroxide signaling: studies with a novel anti-dimedone sulfenic acid antibody. Antioxid Redox Signal 14: 49-60, 2011.

65. Manta B, Hugo M, Ortiz C, Ferrer-Sueta G, Trujillo M, Denicola A. The peroxidase and peroxynitrite reductase activity of human erythrocyte peroxiredoxin 2. Arch Biochem Biophys 484: 146-54, 2009.

66. Marguerat S, Schmidt A, Codlin S, Chen W, Aebersold R, Bahler J. Quantitative analysis of fission yeast transcriptomes and proteomes in proliferating and quiescent cells. Cell 151: 67183, 2012. 
67. Menger KE, James AM, Cocheme HM, Harbour ME, Chouchani ET, Ding S, Fearnley IM, Partridge L, Murphy MP. Fasting, but Not Aging, Dramatically Alters the Redox Status of Cysteine Residues on Proteins in Drosophila melanogaster. Cell Rep 11: 1856-65, 2015.

68. Meyer Y, Buchanan BB, Vignols F, Reichheld JP. Thioredoxins and glutaredoxins: unifying elements in redox biology. Annu Rev Genet 43: 335-67, 2009.

69. Mora-Garcia S, Rodriguez-Suarez R, Wolosiuk RA. Role of electrostatic interactions on the affinity of thioredoxin for target proteins. Recognition of chloroplast fructose-1, 6bisphosphatase by mutant Escherichia coli thioredoxins. J Biol Chem 273: 16273-80, 1998.

70. Murray $\mathrm{Cl}$, Uhrigshardt $\mathrm{H}, \mathrm{O}$ 'Meally RN, Cole RN, Van Eyk JE. Identification and quantification of S-nitrosylation by cysteine reactive tandem mass tag switch assay. Mol Cell Proteomics 11: M111 013441, 2012.

71. Nakao LS, Everley RA, Marino SM, Lo SM, de Souza LE, Gygi SP, Gladyshev VN. Mechanism-based proteomic screening identifies targets of thioredoxin-like proteins. $\mathrm{J}$ Biol Chem 290: 5685-95, 2015.

72. Oh SW, Mukhopadhyay A, Svrzikapa N, Jiang F, Davis RJ, Tissenbaum HA. JNK regulates lifespan in Caenorhabditis elegans by modulating nuclear translocation of forkhead transcription factor/DAF-16. Proc Natl Acad Sci U S A 102: 4494-9, 2005.

73. Ostman A, Frijhoff J, Sandin A, Bohmer FD. Regulation of protein tyrosine phosphatases by reversible oxidation. J Biochem 150: 345-56, 2011.

74. Paget MS, Buttner MJ. Thiol-based regulatory switches. Annu Rev Genet 37: 91-121, 2003.

75. Paulsen CE, Truong TH, Garcia FJ, Homann A, Gupta V, Leonard SE, Carroll KS. Peroxidedependent sulfenylation of the EGFR catalytic site enhances kinase activity. Nat Chem Biol 8: 57-64, 2012.

76. Peskin AV, Pace PE, Behring JB, Paton LN, Soethoudt M, Bachschmid MM, Winterbourn CC. Glutathionylation of the Active Site Cysteines of Peroxiredoxin 2 and Recycling by Glutaredoxin. J Biol Chem 291: 3053-62, 2016.

77. Phelps DC, Hatefi Y. Inhibition of D(--)-beta-hydroxybutyrate dehydrogenase by modifiers of disulfides, thiols, and vicinal dithiols. Biochemistry 20: 453-8, 1981.

78. Poole LB, Klomsiri C, Knaggs SA, Furdui CM, Nelson KJ, Thomas MJ, Fetrow JS, Daniel LW, King SB. Fluorescent and affinity-based tools to detect cysteine sulfenic acid formation in proteins. Bioconjug Chem 18: 2004-17, 2007.

79. Putker M, Madl T, Vos HR, de Ruiter H, Visscher M, van den Berg MC, Kaplan M, Korswagen $\mathrm{HC}$, Boelens R, Vermeulen M, Burgering BM, Dansen TB. Redox-dependent control of FOXO/DAF-16 by transportin-1. Mol Cell 49: 730-42, 2013.

80. Putker M, Vos HR, van Dorenmalen K, de Ruiter H, Duran AG, Snel B, Burgering BM, Vermeulen M, Dansen TB. Evolutionary acquisition of cysteines determines FOXO paralogspecific redox signaling. Antioxid Redox Signal 22: 15-28, 2015.

81. Puyaubert J, Fares A, Reze N, Peltier JB, Baudouin E. Identification of endogenously Snitrosylated proteins in Arabidopsis plantlets: effect of cold stress on cysteine nitrosylation level. Plant Sci 215-216: 150-6, 2014.

82. Qu Z, Meng F, Bomgarden RD, Viner RI, Li J, Rogers JC, Cheng J, Greenlief CM, Cui J, Lubahn DB, Sun GY, Gu Z. Proteomic quantification and site-mapping of S-nitrosylated proteins using isobaric iodoTMT reagents. J Proteome Res 13: 3200-11, 2014.

83. Requejo R, Chouchani ET, James AM, Prime TA, Lilley KS, Fearnley IM, Murphy MP. Quantification and identification of mitochondrial proteins containing vicinal dithiols. Arch Biochem Biophys 504: 228-35, 2010.

84. Rhee SG, Chae HZ, Kim K. Peroxiredoxins: a historical overview and speculative preview of novel mechanisms and emerging concepts in cell signaling. Free Radic Biol Med 38: 1543-52, 2005.

85. Ritz D, Beckwith J. Roles of thiol-redox pathways in bacteria. Annu Rev Microbiol 55: 21-48, 2001.

86. Roos G, Foloppe N, Messens J. Understanding the pK(a) of redox cysteines: the key role of hydrogen bonding. Antioxid Redox Signal 18: 94-127, 2013.

87. Rosenwasser S, Graff van Creveld S, Schatz D, Malitsky S, Tzfadia O, Aharoni A, Levin Y, Gabashvili A, Feldmesser E, Vardi A. Mapping the diatom redox-sensitive proteome provides insight into response to nitrogen stress in the marine environment. Proc Natl Acad Sci U S A 111: 2740-5, 2014. 
88. Samarasinghe KT, Munkanatta Godage DN, VanHecke GC, Ahn YH. Metabolic synthesis of clickable glutathione for chemoselective detection of glutathionylation. J Am Chem Soc 136: 11566-9, 2014.

89. Saurin AT, Neubert H, Brennan JP, Eaton P. Widespread sulfenic acid formation in tissues in response to hydrogen peroxide. Proc Natl Acad Sci U S A 101: 17982-7, 2004.

90. Schafer FQ, Buettner GR. Redox environment of the cell as viewed through the redox state of the glutathione disulfide/glutathione couple. Free Radic Biol Med 30: 1191-212, 2001.

91. Seo YH, Carroll KS. Profiling protein thiol oxidation in tumor cells using sulfenic acid-specific antibodies. Proc Natl Acad Sci U S A 106: 16163-8, 2009.

92. Sethuraman M, McComb ME, Heibeck T, Costello CE, Cohen RA. Isotope-coded affinity tag approach to identify and quantify oxidant-sensitive protein thiols. Mol Cell Proteomics 3: 2738, 2004.

93. Sethuraman M, McComb ME, Huang H, Huang S, Heibeck T, Costello CE, Cohen RA. Isotope-coded affinity tag (ICAT) approach to redox proteomics: identification and quantitation of oxidant-sensitive cysteine thiols in complex protein mixtures. J Proteome Res 3: 1228-33, 2004.

94. Sobotta MC, Liou W, Stocker S, Talwar D, Oehler M, Ruppert T, Scharf AN, Dick TP. Peroxiredoxin-2 and STAT3 form a redox relay for $\mathrm{H} 2 \mathrm{O} 2$ signaling. Nat Chem Biol 11: 64-70, 2015.

95. Soylu I, Marino SM. Cy-preds: An algorithm and a web service for the analysis and prediction of cysteine reactivity. Proteins 84: 278-91, 2016.

96. Sturm N, Jortzik E, Mailu BM, Koncarevic S, Deponte M, Forchhammer K, Rahlfs S, Becker K. Identification of proteins targeted by the thioredoxin superfamily in Plasmodium falciparum. PLOS Pathog 5: e1000383, 2009.

97. Su D, Gaffrey MJ, Guo J, Hatchell KE, Chu RK, Clauss TR, Aldrich JT, Wu S, Purvine S, Camp DG, Smith RD, Thrall BD, Qian WJ. Proteomic identification and quantification of Sglutathionylation in mouse macrophages using resin-assisted enrichment and isobaric labeling. Free Radic Biol Med 67: 460-70, 2014.

98. Su D, Shukla AK, Chen B, Kim JS, Nakayasu E, Qu Y, Aryal U, Weitz K, Clauss TR, Monroe ME, Camp DG, 2nd, Bigelow DJ, Smith RD, Kulkarni RN, Qian WJ. Quantitative site-specific reactivity profiling of S-nitrosylation in mouse skeletal muscle using cysteinyl peptide enrichment coupled with mass spectrometry. Free Radic Biol Med 57: 68-78, 2013.

99. Tao K. In vivo oxidation-reduction kinetics of OxyR, the transcriptional activator for an oxidative stress-inducible regulon in Escherichia coli. FEBS Lett. 457: 90-92, 1999.

100. Toledano MB, Delaunay-Moisan A, Outten CE, Igbaria A. Functions and cellular compartmentation of the thioredoxin and glutathione pathways in yeast. Antioxid Redox Signal 18: 1699-711, 2013.

101. Toledano MB, Kullik I, Trinh F, Baird PT, Schneider TD, Storz G. Redox-dependent shift of OxyR-DNA contacts along an extended DNA-binding site: a mechanism for differential promoter selection. Cell 78: 897-909, 1994.

102. Tristan C, Shahani N, Sedlak TW, Sawa A. The diverse functions of GAPDH: views from different subcellular compartments. Cell Signal 23: 317-23, 2011.

103. Trotter PJ. The genetics of fatty acid metabolism in Saccharomyces cerevisiae. Annu Rev Nutr 21: 97-119, 2001.

104. Tu BP, Weissman JS. Oxidative protein folding in eukaryotes: mechanisms and consequences. J Cell Biol 164: 341-6, 2004.

105. Turrens JF. Mitochondrial formation of reactive oxygen species. J Physiol 552: 335-44, 2003.

106. Vivancos AP, Castillo EA, Biteau B, Nicot C, Ayte J, Toledano MB, Hidalgo E. A cysteinesulfinic acid in peroxiredoxin regulates $\mathrm{H} 2 \mathrm{O} 2$-sensing by the antioxidant Pap1 pathway. Proc Natl Acad Sci U S A 102: 8875-80, 2005.

107. Vivancos AP, Castillo EA, Jones N, Ayte J, Hidalgo E. Activation of the redox sensor Pap1 by hydrogen peroxide requires modulation of the intracellular oxidant concentration. Mol Microbiol 52: 1427-35, 2004.

108. Vivancos AP, Jara M, Zuin A, Sanso M, Hidalgo E. Oxidative stress in Schizosaccharomyces pombe: different $\mathrm{H} 2 \mathrm{O} 2$ levels, different response pathways. Mol Genet Genomics 276: 495$502,2006$. 
109. Wang X, Kettenhofen NJ, Shiva S, Hogg N, Gladwin MT. Copper dependence of the biotin switch assay: modified assay for measuring cellular and blood nitrosated proteins. Free Radic Biol Med 44: 1362-72, 2008.

110. Weerapana E, Wang C, Simon GM, Richter F, Khare S, Dillon MB, Bachovchin DA, Mowen K, Baker D, Cravatt BF. Quantitative reactivity profiling predicts functional cysteines in proteomes. Nature 468: 790-5, 2010.

111. Winterbourn CC. Reconciling the chemistry and biology of reactive oxygen species. Nat Chem Biol 4: 278-86, 2008.

112. Winterbourn CC, Hampton MB. Thiol chemistry and specificity in redox signaling. Free Radic Biol Med 45: 549-61, 2008.

113. Wood MJ, Andrade EC, Storz G. The redox domain of the Yap1p transcription factor contains two disulfide bonds. Biochemistry 42: 11982-91, 2003.

114. Wood MJ, Storz G, Tjandra N. Structural basis for redox regulation of Yap1 transcription factor localization. Nature 430: 917-21, 2004.

115. Yan C, Lee LH, Davis LI. Crm1p mediates regulated nuclear export of a yeast AP-1-like transcription factor. EMBO J. 17: 7416-7429, 1998.

116. Yang B, Wu YJ, Zhu M, Fan SB, Lin J, Zhang K, Li S, Chi H, Li YX, Chen HF, Luo SK, Ding YH, Wang LH, Hao Z, Xiu LY, Chen S, Ye K, He SM, Dong MQ. Identification of cross-linked peptides from complex samples. Nat Methods 9: 904-6, 2012.

117. Yang J, Gupta V, Carroll KS, Liebler DC. Site-specific mapping and quantification of protein Ssulphenylation in cells. Nat Commun 5: 4776, 2014.

118. Yang J, Gupta V, Tallman KA, Porter NA, Carroll KS, Liebler DC. Global, in situ, site-specific analysis of protein S-sulfenylation. Nat Protoc 10: 1022-37, 2015.

119. Zaffagnini M, Bedhomme M, Groni H, Marchand CH, Puppo C, Gontero B, Cassier-Chauvat $\mathrm{C}$, Decottignies $\mathrm{P}$, Lemaire SD. Glutathionylation in the photosynthetic model organism Chlamydomonas reinhardtii: a proteomic survey. Mol Cell Proteomics 11: M111 014142, 2012.

120. Zhang X, Yang F, Shim JY, Kirk KL, Anderson DE, Chen X. Identification of arsenic-binding proteins in human breast cancer cells. Cancer Lett 255: 95-106, 2007.

121. Zheng M, Aslund F, Storz G. Activation of the OxyR transcription factor by reversible disulfide bond formation. Science 279: 1718-21, 1998. 


\section{FIGURE LEGENDS}

FIG. 1. Redox modifications of Cys residues by $\mathrm{H}_{2} \mathrm{O}_{2}$. Oxidation of thiol groups in proteins (Prot$\mathrm{SH}$ ) by two electron oxidants such as $\mathrm{H}_{2} \mathrm{O}_{2}$ initially results in sulfenic acid formation (Prot-SOH). This species readily reacts with another proximal thiol to form a disulfide bond (Prot-S-S-Prot'). Sulfenic acid and disulfide bonds are reversible oxidations that can be reduced to the thiol form by the Trx or Grx systems. Sulfenic acid may become further oxidized to sulfinic (Prot- $\left.\mathrm{SO}_{2} \mathrm{H}\right)$ or sulfonic (Prot$\mathrm{SO}_{3} \mathrm{H}$ ) acid forms.

FIG. 2. The Trx and Grx systems control the thiol-disulfide status in cells. Disulfide bonds in proteins can be reduced to the thiol form through a series of reactions that involve oxidoreductases Trxs and Grxs. (A) Trx reduces protein disulfides and it is recycled by Trx reductase (TRR) that uses electrons provided by NADPH. (B) Grx reduces protein disulfides and it is recycled with two molecules of GSH (dithiol Grx, upper panel) or one molecule of GSH (monothiol Grx, lower panel). In both types of Grxs, oxidized GSH is reduced by glutathione reductase (GSHR) which also uses NADPH as the final electron donor.

FIG. 3. Suggested considerations for the preparation of cell extracts for MS analysis. (A) Freezing the thiol redox status in cultures. It is essential to maintain the Cys oxidation status in their in vivo form. This can be accomplished by either acidification of cultures with acids such as TCA or by adding permeable thiol reacting reagents, such as NEM, to the cultures. (B) Different strategies are generally used to enrich Cys-containing proteins or peptides from whole cell extracts in order to reduce sample complexity for MS analysis. (C) Quantification of the ratio of Cys-oxidized peptide per total amount of the specific protein in each biological sample. We propose the isotopic or isobaric labeling not only of Cys-containing peptides (for instance, with ICAT) but also of all proteins in whole cell extracts (non-enriched fractions; for instance, using iTRAQ).

FIG. 4. Proteomic strategies to analyze reversible Cys oxidation. (A) General strategy based on the biotin switch assay to investigate reversible Cys modifications. After culture acidification with TCA, 
free thiols in proteins (SH) are blocked with an alkylating reagent (ALK1). In a second step, reversibly oxidized Cys (SOx) are reduced with either a general or a specific Cys reducing agent (see text for details). Finally, originally oxidized Cys are alkylated with a different alkylating reagent (ALK2) which allows enrichment of oxidized proteins and quantification of the resulting peptides. (B) Flowchart to identify vicinal Cys thiols, using phenylarsine oxide (PAO) that crosslinks Cys residues located in close proximity. In a second step, the remaining thiols in the protein are blocked with NEM. Cross-linked thiols are then reduced with 2,3-dimercapto-1-propanesulfonic acid (DMPS) and the resulting thiols are alkylated with a different alkylating agent (ALK). (C) The presence of sulfenic acids in biological samples can be investigated using modified dimedone analogs, such as DYn-2, that directly react with sulfenic acid, allowing the enrichment and quantification of proteins. (D) Disulfide bonds in proteins can be identified by either diagonal electrophoresis or directly by newly developed MS software such as pLink-SS.

FIG. 5. Schematic representation of the gel-free strategy to identify and quantify reversibly oxidized Cys by using the ICAT technology on a proteomic scale. TCA extracts are prepared from two biological conditions (1 and 2). Free thiols in the extracts are first blocked with IAM. Upon reduction of reversibly oxidized Cys with TCEP, the resulting thiols are alkylated with either light (B${ }^{12} \mathrm{C}$-IAM, sample 1) or heavy (B- ${ }^{13} \mathrm{C}$-IAM, sample 2) ICAT reagents. Labeled protein extracts are then mixed and digested with trypsin. ICAT-labeled peptides are affinity-purified with streptavidin beads, and analyzed through MS. To quantify individual proteins, small fractions of protein extracts prior to ICAT labeling are digested with trypsin, and the resulting peptides are labeled at their amino groups with light (sample 1) or heavy (sample 2) reagents derivative of formaldehyde or ITRAQ. The resulting peptides are mixed, and analyzed through MS.

FIG. 6. Electrophoretic approaches to study thiol switches. Acidic whole cell extracts (WCE) of untreated (unt) and $\mathrm{H}_{2} \mathrm{O}_{2}$-treated cultures can be processed through SDS-PAGE followed by Western blot using antibodies against a specific protein (Prot), using four slightly different protocols. (A) Oxidized proteins are detected by specific purification with biotin-HPDP. Using this approach, free thiols are blocked with IAM and reversibly oxidized thiols are reduced with DTT or TCEP. Resulting 
thiols are biotin-HPDP-labeled. Proteins labeled with HPDP are enriched with streptavidin sepharose beads (-avidin), and eluted with DTT. The presence of a specific protein (Prot) in WCE and eluted fractions is then tested with standard SDS-PAGE and Western blot. (B) The oxidation of a given protein may trigger a structural change resulting in a electrophoretic mobility shift. In this case, free thiols in WCE are alkylated with IAM, and the difference of mobility between the reduced and the oxidized protein (red. Prot and ox. Prot) is analyzed through non-reducing SDS-PAGE and Western blot. (C) Use of a high mass alkylating agent such as AMS to differentiate reduced and oxidized proteins through standard SDS-PAGE and Western blot. (D) $\mathrm{H}_{2} \mathrm{O}_{2}$ can trigger inter-molecular disulfide formation. In this case, and after alkylation of free thiols with IAM, the different electrophoretic migration of monomeric vs. dimeric forms can be easily determined in WCE by non-reducing SDSPAGE and Western blot.

FIG. 7. Bacterial and eukaryotic thiol switches. (A) The E. coli OxyR transcription factor is a $\mathrm{H}_{2} \mathrm{O}_{2}$ sensor, and activator of an antioxidant response. Oxidized OxyR, with an intra-molecular disulfide bond, is reduced to the inactive state by the GSH/Grx1 system. (B) Activation of the budding yeast Yap1 transcription factor by $\mathrm{H}_{2} \mathrm{O}_{2}$ is mediated through the Gpx Gpx3. See text for details. (C) The Prx Tpx1 mediates the $\mathrm{H}_{2} \mathrm{O}_{2}$-dependent oxidation of the fission yeast transcription factor Pap1. See text for details. 
Table 1 Reagents and strategies to study reversible Cys modifications at the proteome level

\begin{tabular}{|c|c|c|c|}
\hline \multicolumn{4}{|c|}{ Reversible thiol oxidation } \\
\hline & Advantages & Limitations & References \\
\hline OxICAT & $\begin{array}{c}\text { Cleavable biotin } \\
\text { Data is independent on } \\
\text { protein levels }\end{array}$ & $\begin{array}{l}\text { Limited to two conditions } \\
\text { Low sensitivity } \\
\text { Expensive }\end{array}$ & $\begin{array}{c}(9,10,35,51,58,67 \\
87)\end{array}$ \\
\hline ICAT & $\begin{array}{c}\text { Cleavable biotin } \\
\text { High sensitivity } \\
\text { Adapted protocols to } \\
\text { quantify total protein }\end{array}$ & $\begin{array}{l}\text { Limited to two biological } \\
\text { conditions }\end{array}$ & $(25,31,32,55,81)$ \\
\hline $\begin{array}{l}\text { Cys- and lodo- } \\
\text { TMT }\end{array}$ & Multiple samples & Complex data analysis & $(36,70,82)$ \\
\hline \multicolumn{4}{|c|}{ Cys reactivity profiling } \\
\hline ICAT & Commercially available & Not cell permeable & $(92,93)$ \\
\hline IsoTOP-ABPP & $\begin{array}{l}\text { Small molecule } \\
\text { Adapted to conjugation } \\
\text { by click chemistry }\end{array}$ & Not cell permeable & $(22,110)$ \\
\hline $\begin{array}{l}\alpha \text {-bromomethyl } \\
\text { ketone }\end{array}$ & $\begin{array}{l}\text { Cell permeable } \\
\text { Not cell toxic }\end{array}$ & Only one study & (1) \\
\hline \multicolumn{4}{|l|}{ Cys proximity } \\
\hline PAO & Highly specific & $\begin{array}{c}\text { Only one study } \\
\text { Large number of steps } \\
\text { Complex experimental controls }\end{array}$ & (83) \\
\hline \multicolumn{4}{|c|}{ Specific Cys oxidations } \\
\hline $\begin{array}{c}\mathrm{SOH} \\
\text { Use of Dimedone }\end{array}$ & $\begin{array}{l}\text { Availability of several } \\
\text { versions of modified } \\
\text { dimedone and } \\
\text { enrichment strategies }\end{array}$ & & $\begin{array}{c}(2,16,53,60,64,75 \\
91,117,118)\end{array}$ \\
\hline $\begin{array}{l}\text { Intra or inter } \\
\text { protein disulfides } \\
\text { Use of 2D gels }\end{array}$ & $\begin{array}{l}\text { Simple and robust } \\
\text { technique }\end{array}$ & Low sensitivity & $(14)$ \\
\hline $\begin{array}{l}\text { Intra or inter } \\
\text { protein disulfides } \\
\text { Use of pSS-Link) }\end{array}$ & $\begin{array}{l}\text { High throughput } \\
\text { High sensitivity }\end{array}$ & Only one study & (62) \\
\hline $\begin{array}{c}\text { Mixed disulfides } \\
\text { with GSH } \\
\text { Use of GSH-Biotin }\end{array}$ & $\begin{array}{l}\text { Availability of several } \\
\text { versions of biotin- } \\
\text { modified GSH }\end{array}$ & $\begin{array}{c}\text { Changes GSH-GSSG } \\
\text { equilibrium }\end{array}$ & $(15,88,97,119)$ \\
\hline
\end{tabular}


Table 1 Reagents and strategies to study reversible Cys modifications at the proteome level

\begin{tabular}{|c|c|c|c|}
\hline \multicolumn{4}{|c|}{ Reversible thiol oxidation } \\
\hline & Advantages & Limitations & References \\
\hline OXICAT & $\begin{array}{l}\text { Cleavable biotin } \\
\text { Data is independent on } \\
\text { protein levels }\end{array}$ & $\begin{array}{l}\text { Limited to two conditions } \\
\text { Low sensitivity } \\
\text { Expensive }\end{array}$ & $\begin{array}{c}(9,10,35,51,58,67 \\
87)\end{array}$ \\
\hline ICAT & $\begin{array}{l}\text { Cleavable biotin } \\
\text { High sensitivity } \\
\text { Adapted protocols to } \\
\text { quantify total protein }\end{array}$ & $\begin{array}{l}\text { Limited to two biological } \\
\text { conditions }\end{array}$ & $(25,31,32,55,81)$ \\
\hline $\begin{array}{l}\text { Cys- and lodo- } \\
\text { TMT }\end{array}$ & Multiple samples & Complex data analysis & $(36,70,82)$ \\
\hline \multicolumn{4}{|c|}{ Cys reactivity profiling } \\
\hline ICAT & Commercially available & Not cell permeable & $(92,93)$ \\
\hline IsoTOP-ABPP & $\begin{array}{l}\text { Small molecule } \\
\text { Adapted to conjugation } \\
\text { by click chemistry }\end{array}$ & Not cell permeable & $(22,110)$ \\
\hline $\begin{array}{l}\alpha \text {-bromomethyl } \\
\text { ketone }\end{array}$ & $\begin{array}{l}\text { Cell permeable } \\
\text { Not cell toxic }\end{array}$ & Only one study & (1) \\
\hline \multicolumn{4}{|l|}{ Cys proximity } \\
\hline PAO & Highly specific & $\begin{array}{c}\text { Only one study } \\
\text { Large number of steps } \\
\text { Complex experimental controls }\end{array}$ & (83) \\
\hline \multicolumn{4}{|c|}{ Specific Cys oxidations } \\
\hline $\begin{array}{c}\mathrm{SOH} \\
\text { Use of Dimedone }\end{array}$ & $\begin{array}{l}\text { Availability of several } \\
\text { versions of modified } \\
\text { dimedone and } \\
\text { enrichment strategies }\end{array}$ & & $\begin{array}{c}(2,16,53,60,64,75 \\
91,117,118)\end{array}$ \\
\hline $\begin{array}{l}\text { Intra or inter } \\
\text { protein disulfides } \\
\text { Use of 2D gels }\end{array}$ & $\begin{array}{l}\text { Simple and robust } \\
\text { technique }\end{array}$ & Low sensitivity & (14) \\
\hline $\begin{array}{l}\text { Intra or inter } \\
\text { protein disulfides } \\
\text { Use of pSS-Link) }\end{array}$ & $\begin{array}{l}\text { High throughput } \\
\text { High sensitivity }\end{array}$ & Only one study & (62) \\
\hline $\begin{array}{c}\text { Mixed disulfides } \\
\text { with GSH } \\
\text { Use of GSH-Biotin }\end{array}$ & $\begin{array}{l}\text { Availability of several } \\
\text { versions of biotin- } \\
\text { modified GSH }\end{array}$ & $\begin{array}{c}\text { Changes GSH-GSSG } \\
\text { equilibrium }\end{array}$ & $(15,88,97,119)$ \\
\hline
\end{tabular}




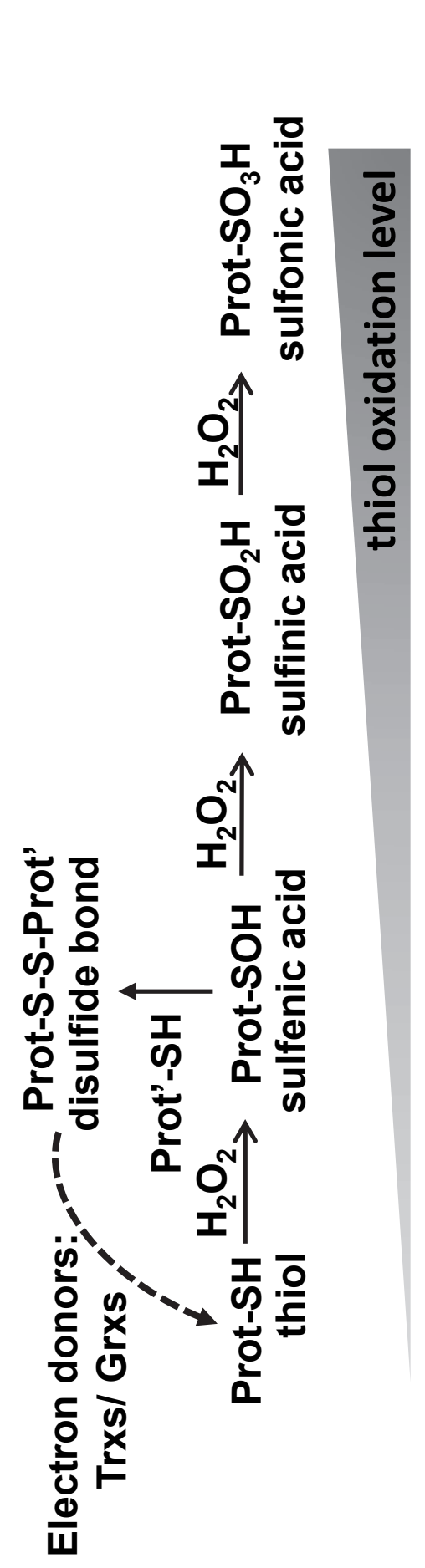



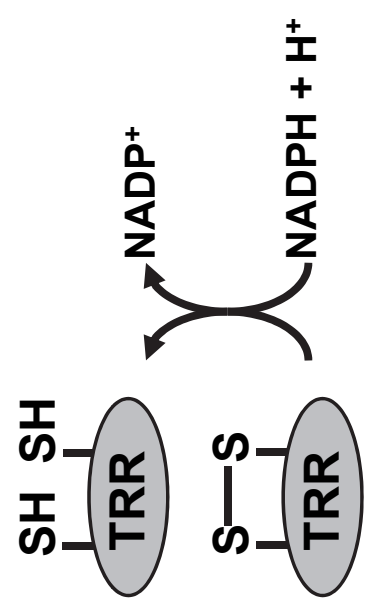

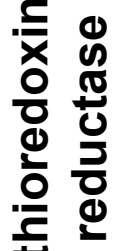

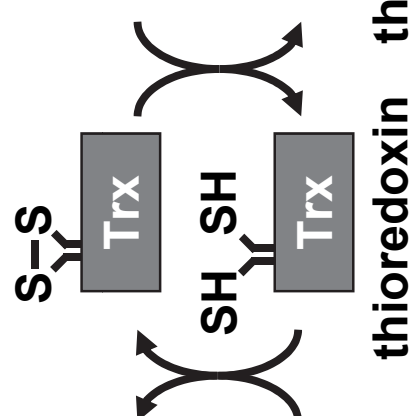

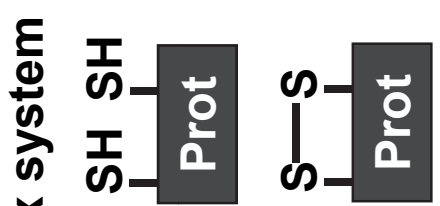

론

ㄴ

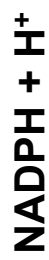

量
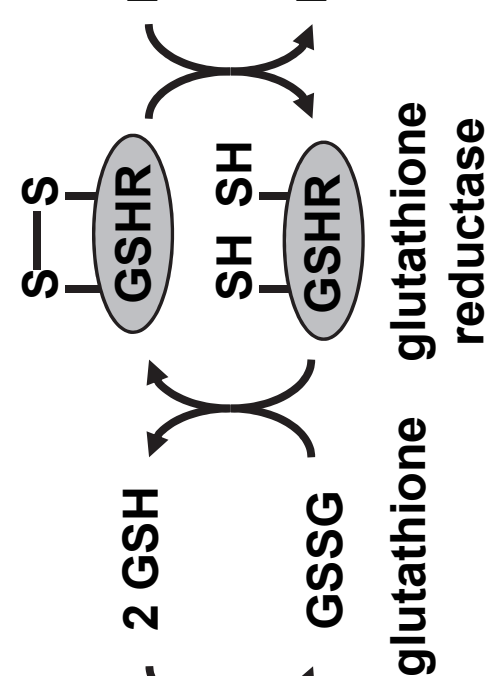

圭

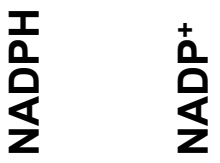

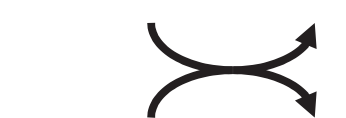

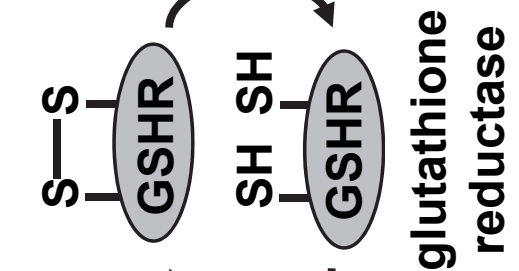

$\frac{0}{0}$
$\frac{0}{0}$
$\frac{0}{0}$
$\frac{1}{x}$
0
$\frac{d}{\pi}$
$\frac{d}{5}$
$\frac{5}{0}$

焉 के

产

(1)

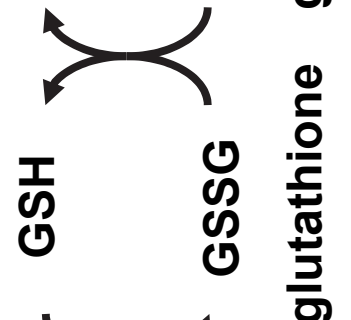

ह

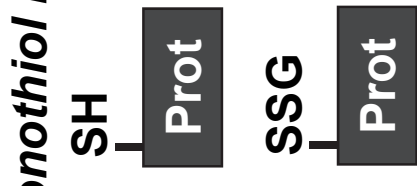

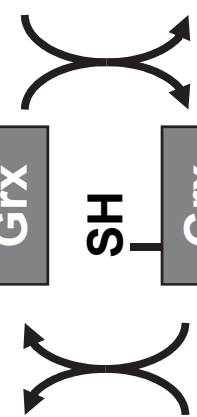




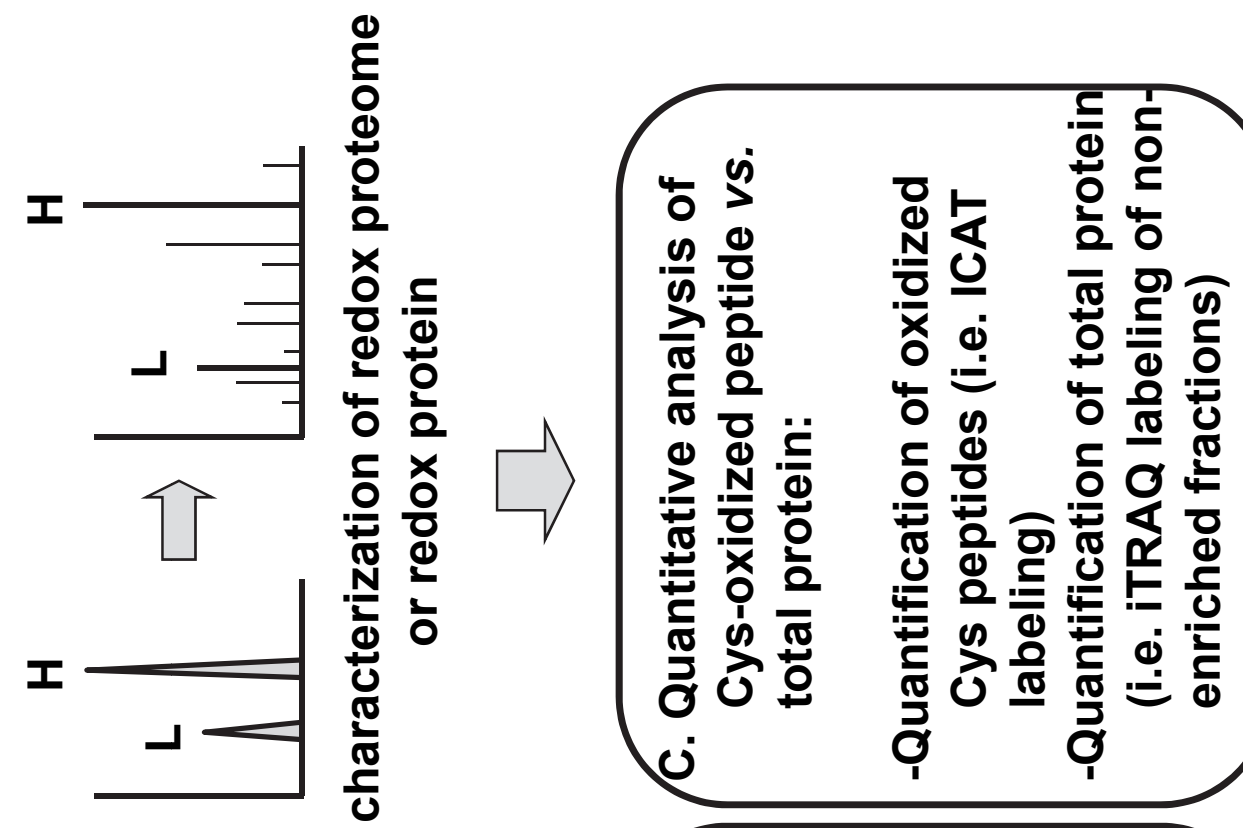

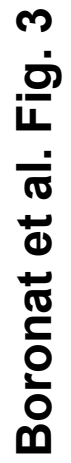

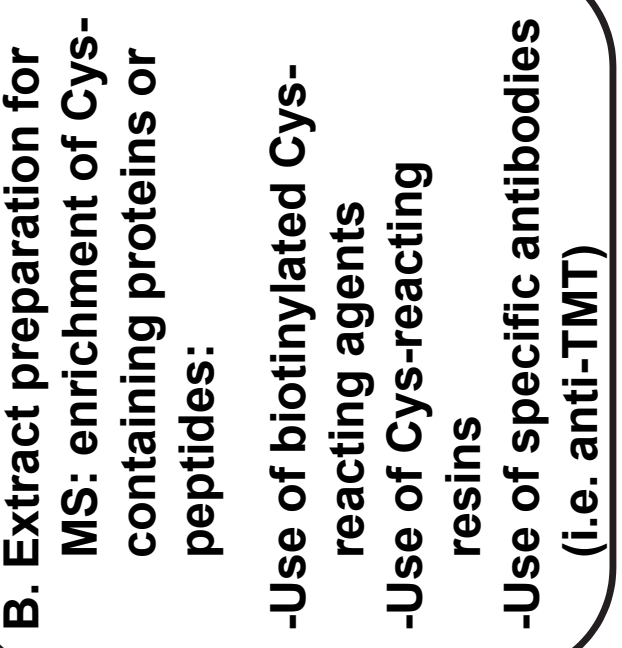
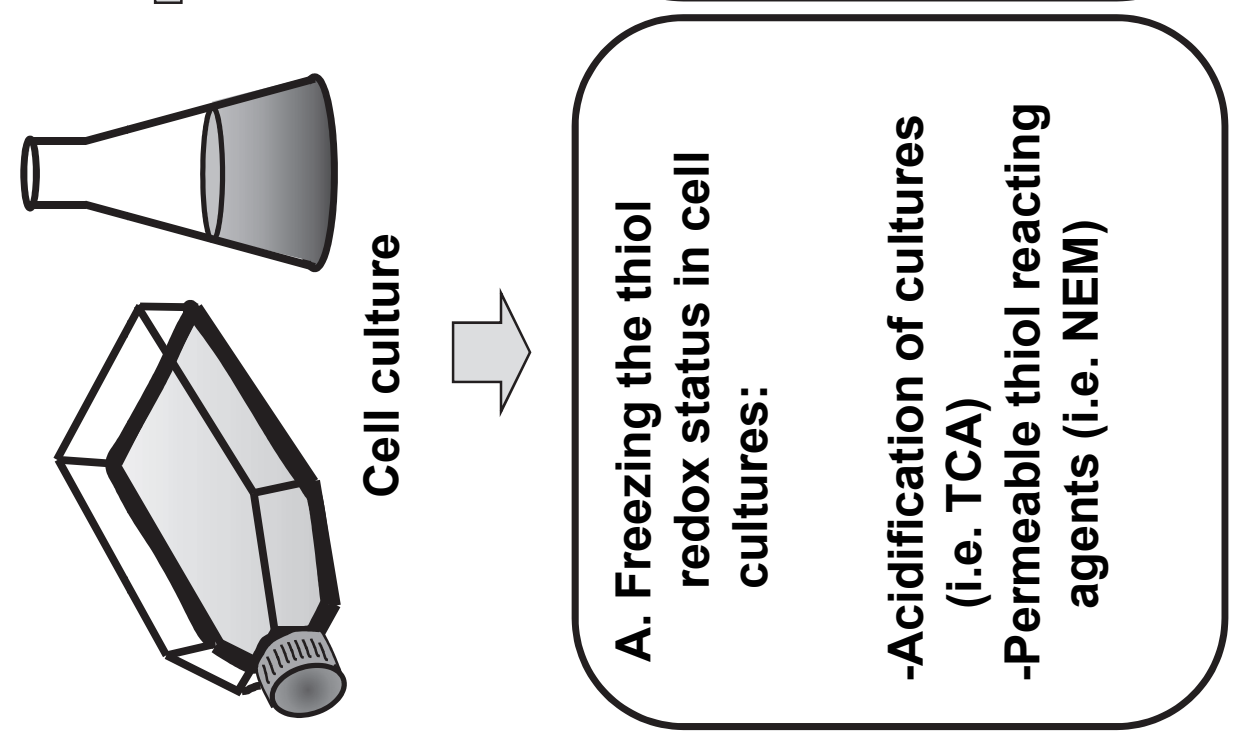


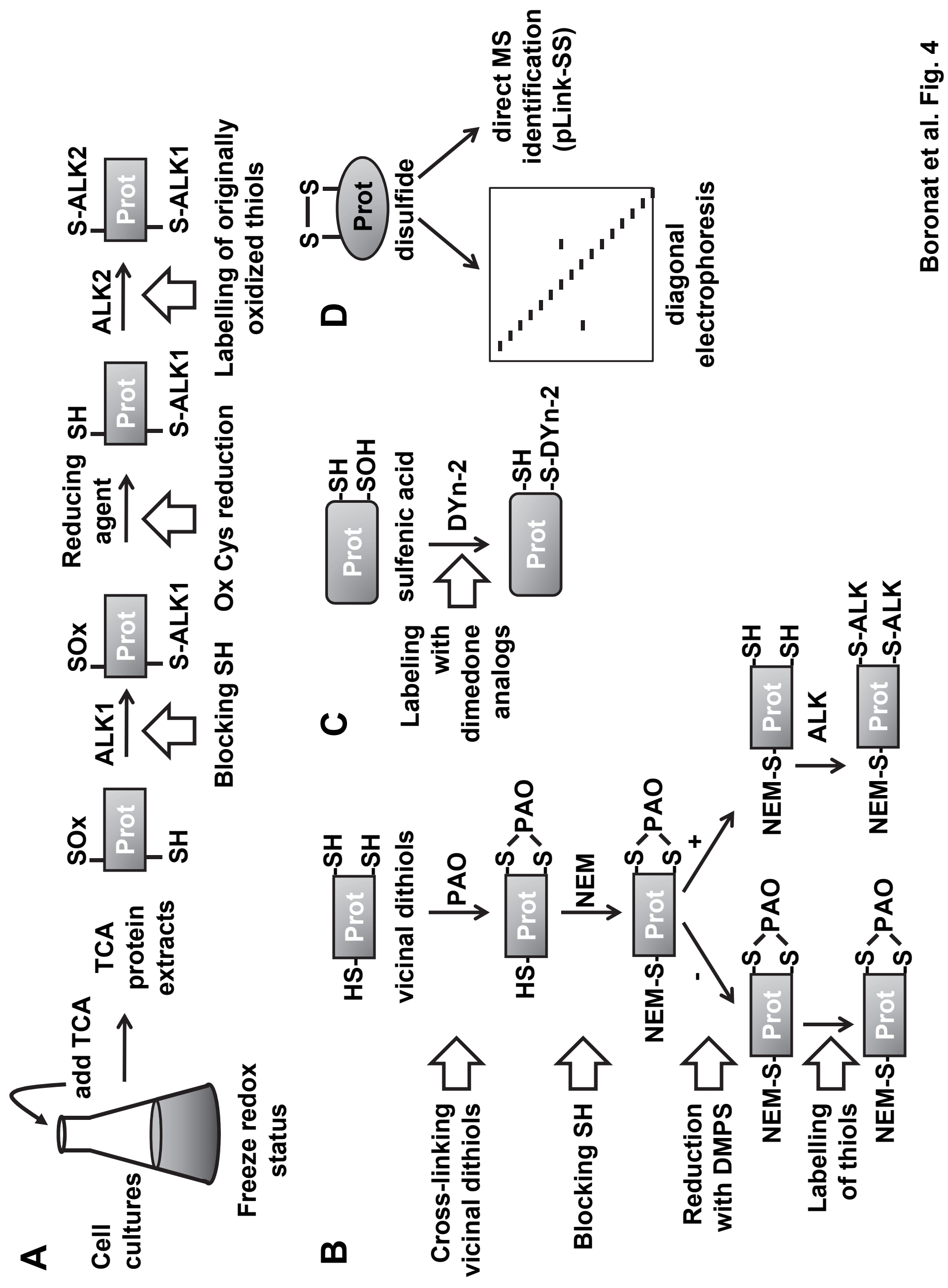




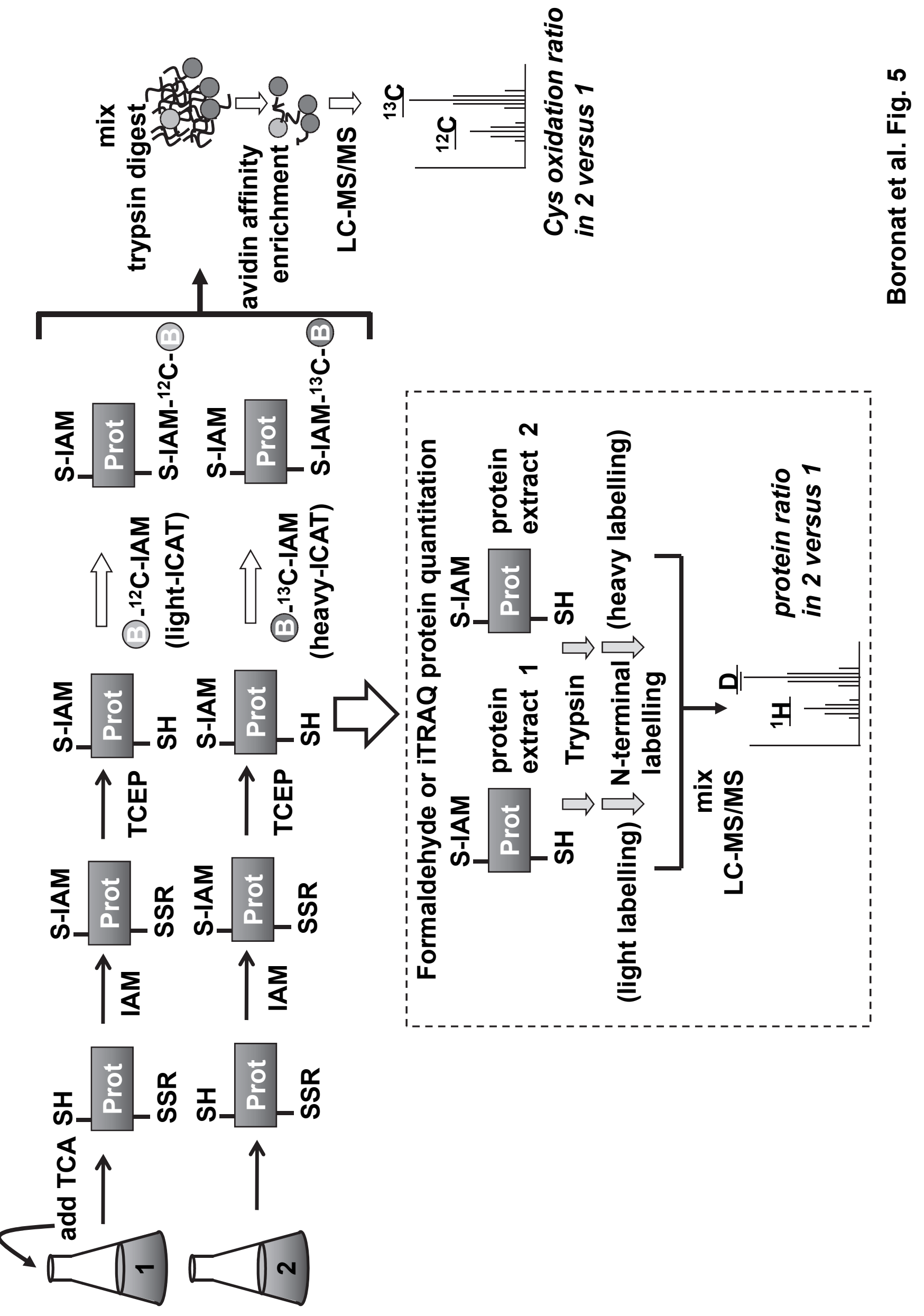




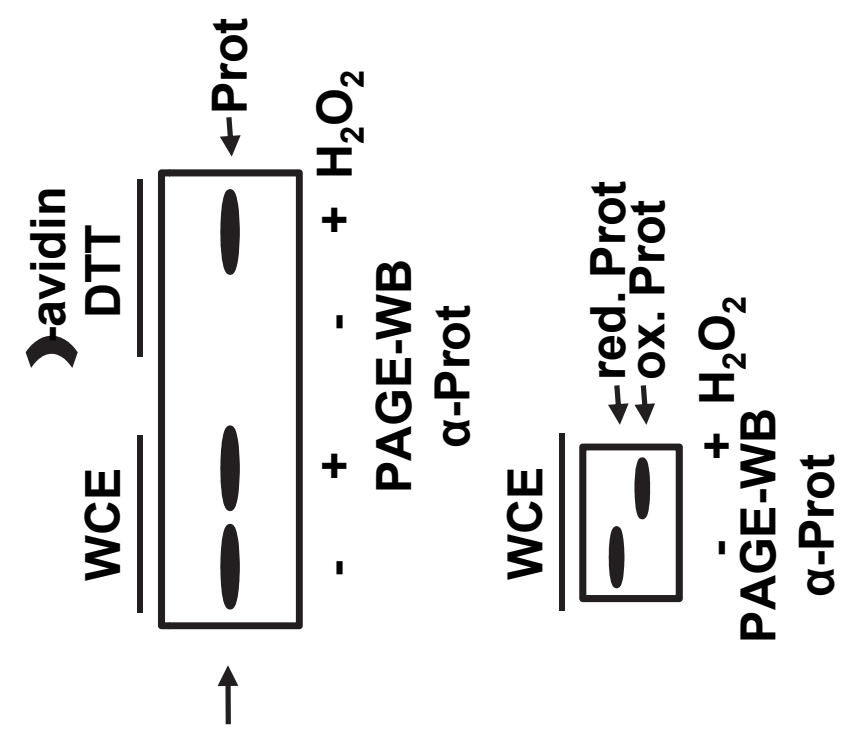

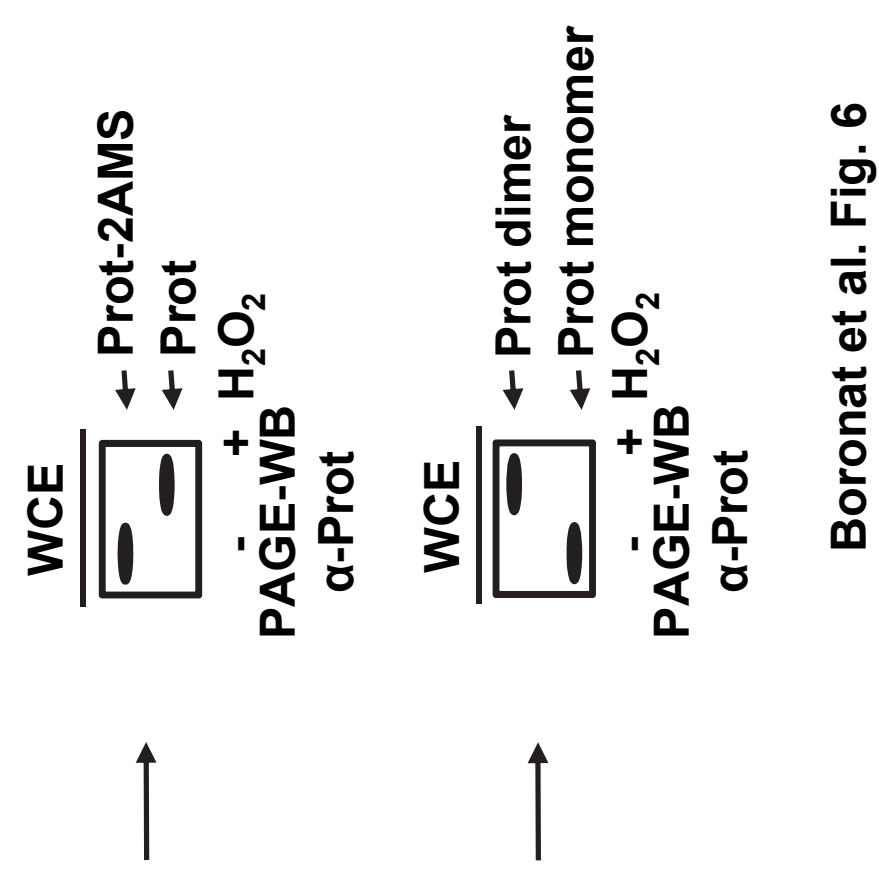

"301

क-<smiles>CCCC</smiles>

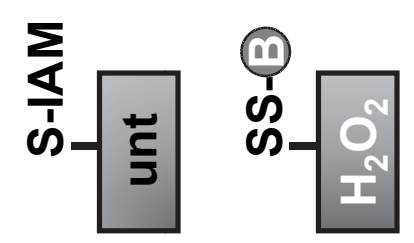

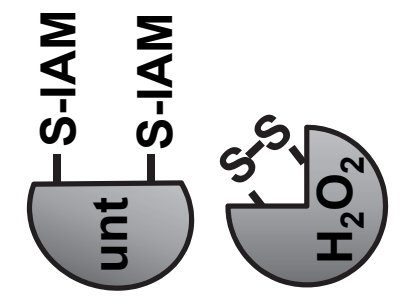

$\sum_{\infty}^{\infty}$

它-

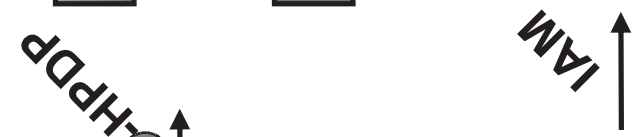

$3 / 4$

4

301

\&

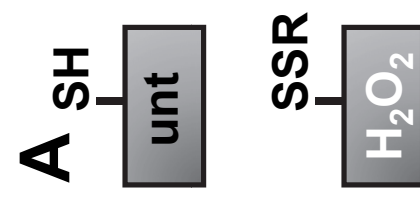

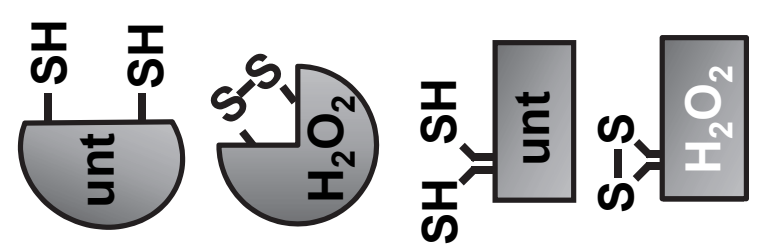

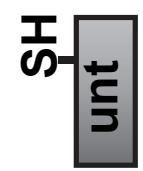

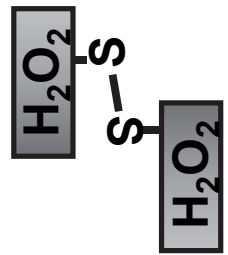

m $U$

$\frac{0}{\frac{0}{0}} \frac{u}{3}$
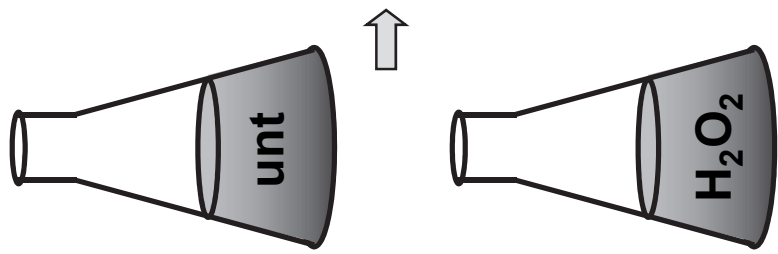
홈
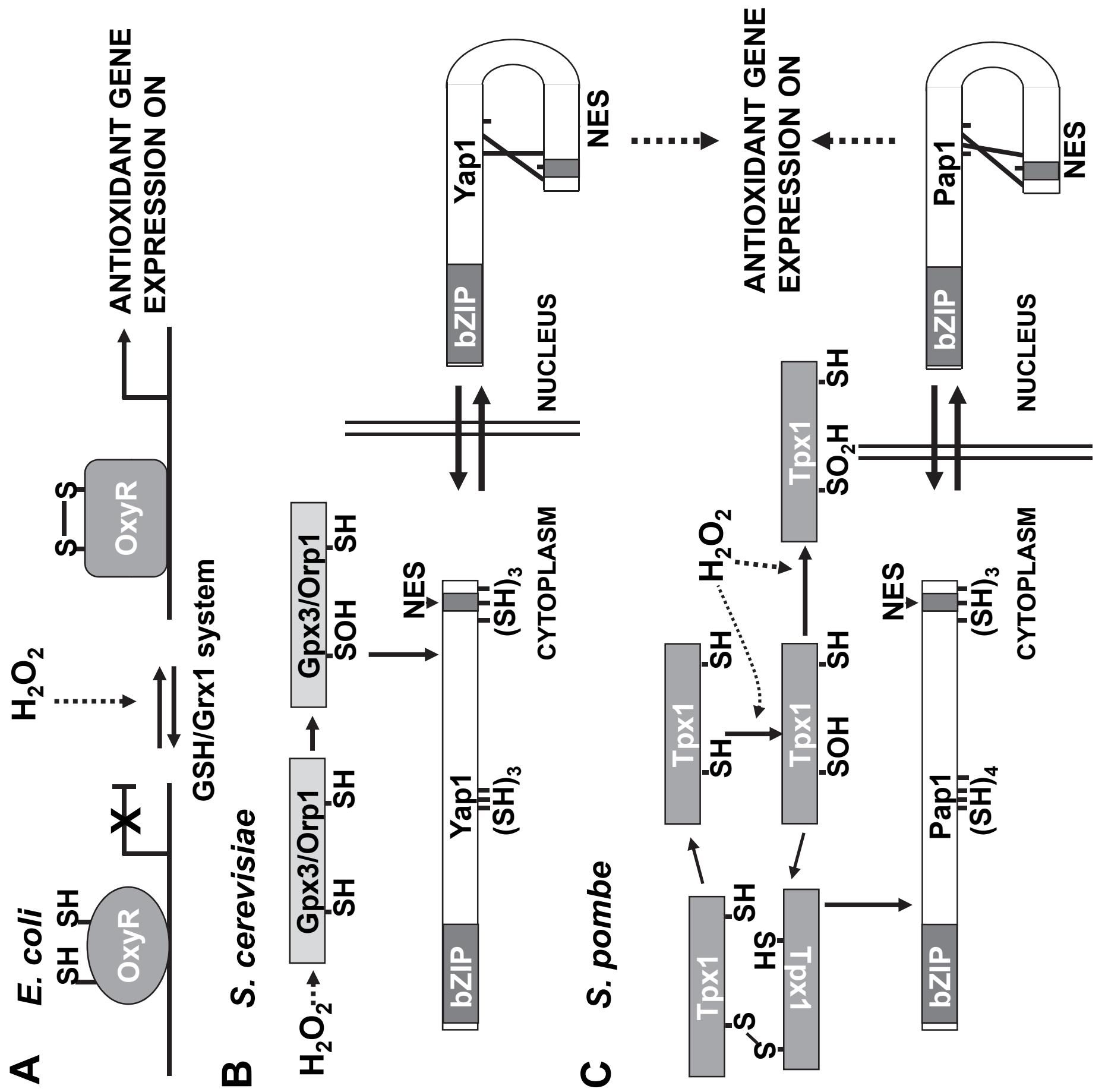